\title{
Phonetic and Phonological Aspects of Slavic Sibilant Fricatives
}

\author{
Marzena Zygis \\ Zentrum für Allgemeine Sprachwissenschaft \\ marzena@zas.gwz-berlin.de
}

\begin{abstract}
In this article I reanalyze sibilant inventories of Slavic languages by taking into consideration acoustic, perceptive and phonological evidence. The main goal of this study is to show that perception is an important factor which determines the shape of sibilant inventories. The improvement of perceptual contrast essentially contributes to creating new sibilant inventories by (i) changing the place of articulation of the existing phonemes (ii) merging sibilants that are perceptually very close or (iii) deleting them.

It has also been shown that the symbol š traditionally used in Slavic linguistics corresponds to two sounds in the IPA system: it stands for a postalveolar sibilant $(\delta)$ in some Slavic languages, as e.g. Bulagarian, Czech, Slovak, some Serbian and Croatian dialects, whereas in others like Polish, Russian, Lower Sorbian it functions as a retroflex (s). This discrepancy is motivated by the fact that $\int$ is not optimal in terms of maintaining sufficient perceptual contrast to other sibilants such as $s$ and 6 . If $\int$ occurs together with $s$ (and $s^{j}$ ) there is a considerable perceptual distance between them but if it occurs with 6 in an inventory, the distance is much smaller. Therefore, the strategy most languages follow is the change from a postalveolar to a retroflex sibilant.
\end{abstract}

\section{Introduction}

Sibilant inventories in the languages of the world exibit certain preferences with respect to place contrasts. According to Maddieson (1984:44) about $83 \%$ of the 317 languages in his survey have some kind of 's-sound', which is either dental or alveolar. 'If a language contains another sibilant it is mostly $\int / 3$. Only in a small number of languages there is a three-way place contrast among sibilants. The most common inventories include a dental/alveolar fricative which contrasts either with (i) a postalveolar and retroflex sibilant, i.e. $\mathrm{s} \int \mathrm{s}$, or (ii) a postalveolar and alveolo-palatal one, i.e., $s \int 6$. A sibilant inventory of the latter type is assumed to exist for several Slavic languages, e.g., Croatian (Kordić 1997), Polish (Rubach 1984), Serbian (Kordić 1997), and Upper Sorbian (Šewc 1968).

In this article I reanalyze sibilant inventories of Slavic languages by taking into consideration acoustic, perceptive and phonological evidence. The main goal of this study is to show that perception is an important factor which determines the shape of sibilant inventories. Its influence essentially contributes to creating new phonemic inventories by (i) changing the place of articulation of the exisiting phonemes, (ii) merging phonemes that are acoustically/perceptually very close or (iii) by deleting them.

Strategy (i), which I follow in this paper, will be shown by arguing that the symbol š traditionally used in Slavic linguistics does not correspond to IPA $\int$, as assumed in non-Slavic tradition, but that it stands for the retroflex (s), as e.g. in Polish, Russian, Lower Sorbian. Its retroflexivity results from phonetic and phonological evidence provided in the present study,

Both sounds are often collapsed into one category, which is motivated not only by their phonetic similarity but also by the rarity of the contrast between $/ \mathrm{s} /$ and $/ \mathrm{s} /$ in the languages of the world. In Maddieson's study only four languages display such a contrast: Tzeltal, Karok, Diegueño and Quarani. 
see also Hall (1997a,b), Halle \& Stevens (1997), Hamann (2003). The present investigation contributes to the systemtization of Slavic languages with respect to their postalveolar/ retroflex sibilants. More importantly, the reason why s and not $\int$ is present in these inventories will be shown on the basis of acoustic measurements and explained by the fact that $\int$ is not optimal in terms of maintaining sufficient perceptual contrast to other sibilants such as $\mathrm{s}$ and 6.

The observation that a three-way place contrast /s $\int c /$ is not optimal was made by Hall (1997a) on the basis of the development of Indo-Aryan languages. The main difference between Hall's approach and the one presented here is the source of explanation: while in the former approach is based on phonological features, in my own acoustic/perceptual relations between sibilants are taken into consideration. Furthermore, the explanation proposed here provides answers to several questions concerning sibilant inventories. For example, it shows why the system /s $6 \mathrm{~s} /$ is preferred to $/ \mathrm{s} \quad \mathrm{G} / /$ and $/ \mathrm{s} \int^{\mathrm{j}} \mathrm{s} /$. It explains why alveolo-palatals instead of palatalized dentals/alveolars usually trigger the change from $\int$ to $s$. In addition, it also becomes clear (i) why $\int / \int^{j}$ changes to $s$ in some inventories, while in others remains intact, and (ii) why it is that $\int$ changes and not e.g. 6 .

This study also differs significantly from Flemming (2002). Although he argues that perception plays a crucial role in shaping sibilant inventories, his approach focuses - as far as Polish sibilants are concerned - on the rounding of retroflex sibilants. The present study takes into consideration not only lip rounding but also spectral differences between the sibilants in terms of the center of gravity. The relations proposed between single sibilants are based on results of acoustic experiments. The data basis below is also enlarged by taking palatalized sibilants into consideration.

As previously mentioned, sibilant inventories of Slavic languages serve as the subject of the present investigation. This is motivated by the fact that these languages are known for their sibilant richness and show a clear distinction between two, three or four sibilant categories. In addition, they are subject to ongoing changes illustrating important phenomena discussed in this study.

The article is organized as follows; In section 2, I discuss the phonetic and phonological evidence for different places of sibilant articulation. Belorussian, Bulgarian, Croatian, Czech, Polish and its dialects, Russian, Serbian and its dialects, Slovak, Lower and Upper Sorbian, as well as Ukrainian are taken into consideration. In section 3, I show similarities and differences between Slavic and Indo-Aryan sibilant systems. In section 4, results of an acoustic experiment of Bulgarian, Polish, and Russian fricatives and discuss their relevance for shaping sibilant systems are presented. Finally, in section 5, main conclusions are laid out.

\section{Sibilants in Slavic languages}

Although the term sibilant refers to both fricatives and affricates, the present discussion is focused on sibilant fricatives, especially in the experimental part of the study. But for the sake of completness both fricatives and affricates are provided in every sibilant system analyzed below. 


\subsection{Standard Polish and its dialects}

In Standard Polish, the inventory of which is shown in (1), both fricatives and affricates (voiced and voiceless) are attested at three different places of articulation: alveolar, retroflex, and alveolo-palatal.

(1) Standard Polish

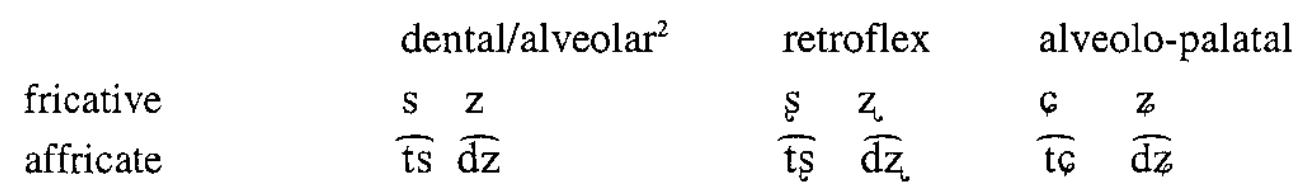

It should be stressed that the retroflex status of the sibilant in Polish [s] is by no means commonly accepted, especially by Slavic researches who transcribe this sound as postalveolar with the IPA symbol $\int$ (cf. Biedrzycki 1974, Dogil 1990, Rubach 1984) or with the equivalent Slavic one š (Dłuska 1983, Gussmann 1980, Kuraszkiewicz 1972, Wierzchowska 1980, Stieber 1958, 1966, 1969, 1973, Szpyra 1995). I am not aware of any study of 'Slavic origin' in which the symbol $s$ or the term 'retroflex' has been employed. One of the reasons for preferring $\int$ over $\$$ seems to be that from a perceptual point of view $\mathbf{s}$ is much more similar to a postalveolar $\int$ (as in English or German) rather than to a true retroflex s (as in Tamil). On the other hand, articulatory studies, cf. Keating (1993), Ladefoged \& Maddieson (1996), Wierzchowska (1980:64), and phonological investigation, cf. Hall (1997), Hamann (2002a), provide convincing evidence for the retroflex nature of the Polish sibilant. In this study I assume that the sibilant under consideration is a (flat) retroflex $s$ for (i) articulatory, (ii) phonological, and (iii) acoustic and perceptive reasons.

Leaving aside acoustic perceptive aspects, which will be discussed in section 4 , let us concentrate here on articulatory and phonological arguments. As far as the articulation of the sibilant is concerned, Wierzchowska (1980:64) has shown that the sibilant is articulated with a tongue tip, cf. (2). What is characteristic for this sound is also the fact that the tongue is flat and not domed as in the case of a postalveolar $\int$. The difference in the tongue shape between $\mathrm{s}$, as in Polish, and $\int$, as in Bulgarian, is shown by $\mathrm{x}$-ray tracings in (2a) and (2b), respectively.

(2)
a. Polish s, cf. Wierzchowska (1980:64)
b. Bulgarian S, cf. Stojkov (1955:39)
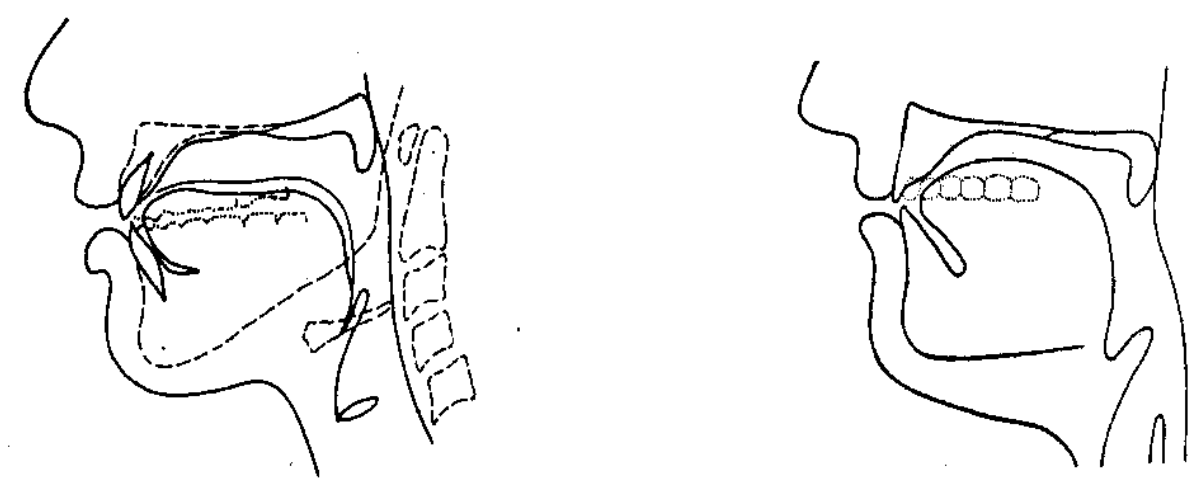

In addition, Rochon \& Pompino-Marschall (1999), investigating the articulation of coronals in Polish by means of articulography (EMA) and electropalatography (EPG), show that the

$\overline{2}$ In the following I will use only alveolars which comprise both alveolars and optionally dentals. 
sibilant under consideration is produced with the tongue tip that is essentially bent backwards in relation to its position for Polish [s] or [t]which confirms the retroflexivity of $[s]$.

Apart from these articulatory arguments there is also phonological evidence in favor of the retroflex status of the Polish sibilant. It is provided by a rule called Retraction according to which [i] is turned into the high central unrounded vowel [i], after s, $z_{\text {, }}$ cf. Rubach (1984). For example the plural form Holend $/ r+i /{ }^{4}$ 'Dutchman' nom.pl. is pronounced as Holend[zi] and not ${ }^{*}$ Holend[zi], while chto/p $+i$ / 'farmer' nom.pl. is regularly realized as chto[pi], cf. Rubach (1984:201-206). As observed by Hamann (2002a, 2003), this rule mirrors the fact that $s, \mathrm{z}$ are retroflexes because they are not compatible with high front vowels from an articulatory point of view. If $s / z$ is followed by $i$ or $j$, then in changes to a postalveolar $\rho^{j}$. The palatalized postalveolar $\rho^{j}$ appears in a few foreign words before $i$ or $j$, e.g. To[ $\left.\int^{j}\right]$ iba and proper names, e.g. [j] ]aak 'Sjaak'.

Let us now consider to Polish dialects. As shown in (1) Standard Polish has a threeway phonemic place contrast, which is reduced in almost every Polish dialect to a two-way contrast. What is striking about the dialectal phonemic inventories is that retroflexes and alveolo-palatals are affected by various processes, while alveolars remain intact. In the following, three different dialects are discussed with respect to sibilants, namely Mazovian, Kashubian and Mazurian.

In Mazovian, ${ }^{6}$ Standard Polish retroflexes are realized as alveolars, cf. examples in (3). Alveolo-palatals and alveolars are pronounced as in Standard Polish.
Standard Polish
Mazovian
[z]yto
[z]yto 'rye' nom.sg.
[ts] as
$[\mathrm{ts}]$ as 'time' nom.sg.

In Kashubian, ${ }^{7}$ the alveolo-palatals of Standard Polish are realized as alveolars, which is illustrated by the examples in (4). Alveolars remain intact.

Standard Polish
$[6]$ pi
wi[ $[\overline{\mathrm{dz}}] \mathrm{eli}$

Kashubian

[s]pi 'he sleeps'

In the context of this change, the question arises as to how the retroflexes of Standard Polish are realized in Kashubian. Although there is no IPA transcription of these sounds available, I

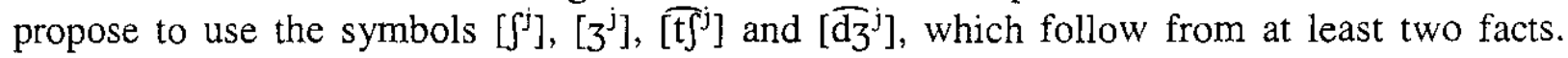
First, in descriptive studies, they are commonly referred to as 'soft postalveolars' (e.g., Topolińska 1974, Dejna 1984 and references therein) and are therefore transcribed as $\xi, \varepsilon, \varepsilon, \varepsilon, \xi$, where the diacritic (') marks the 'softness' of š, $\check{z}, \breve{c}, \breve{z}$. Secondly, my preliminary analysis of recordings I made during fieldwork in the Kashubian area indicate that they are the same as palatalized postalveolars, which occur in Standard Polish foreign words, e.g., [3 $3^{j_{i}}$ ] wago

3 The rule also applies after hard dental/alveolar consonants such as $t, d, s, z, \overline{t s}, \overline{d z}, r$ as well as affricates $\overparen{t s}$ $\overline{\mathrm{dz}}$.

4 The suffix $-i$ causes the palatalization of the stem-final consonant; in this case $r \rightarrow z_{i}$ In cyclic phonology, Retraction applies after Coronal Palatalization, cf. Rubach (1984:201-206).

3 The palatalized counterparts of the retroflex sounds remain postalveolar $\rho^{j} 3^{j}$ and not $s^{j} z^{j}$. This follows from a universal assumption that retroflexes cannot be palatalized, cf. discussion on this topic in Hamann (2002b).

6 Mazovian is spoken in Mazovia (except the extreme northeast), in Małopolska, (except the areas between the rivers Wisłok and San, the Upper Wieprz and Bug), and in northern Silesia.

7. Kashubian is spoken in the northern part of Poland, close to Gdańsk. 
'Żiwago' prop.name. To conclude, I assume that Standard Polish retroflexes surface in Kashubian as palatalized postalveolars, as shown in examples in (5).

(5)
Standard Polish
Kashubian
[s]aro
$\left[\int^{\mathrm{j}}\right.$ ]aro
'grey'
[s]arpie
$\left[\int^{j}\right]$ arpie
'he pulls'

Finally, in Mazurian and Jabłonków dialects, retroflexes and alveolpalatals merged to palatalized postalveolars. Stieber (1996:81) mentions that this merger resulted in a series of sibilants, which he represents as $\breve{s}, \check{\mathbf{z}}, \check{e}, \breve{z}$. The same symbols are used by Dejna (1984: 71). In (6) I provide the corresponding IPA symbols, i.e. $\int^{j}, 3^{j}, \overline{\mathrm{t}}^{\mathrm{j}}, \overline{\mathrm{d}} \mathrm{z}^{\mathrm{j}}$.

(6) Standard Polish

Mazurian \& Jablonków
[z]yto
$\left[3^{\mathrm{j}}\right] \mathrm{yto}$
[ţ] as
$\left[\widehat{t g}^{\mathrm{j}}\right] \mathrm{ses}$
'rye' nom.sg.
[c]ano
$\left[\int^{\mathrm{j}}\right]$ ano
'time' nom.sg.
'hay' nom.sg.

To summarize, the examples presented above have shown that the three-way phonemic contrast of Standard Polish is reduced to two contrasting sibilants in the dialects. The table in (7) summarizes the 'sibilant situation' in Poland. Notice that although palatalized postalveolars occur in both Kashubian and Mazurian/ Jabłonków dialects they are differently realized in comparison to Standard vocabulary: in the first case $\int^{j} 3^{j}$ occur where Standard Polish retroflexes are realized and in the latter case they are pronounced in positions where both Standard Polish retroflexes and alveolo-palatals occur.

(7)

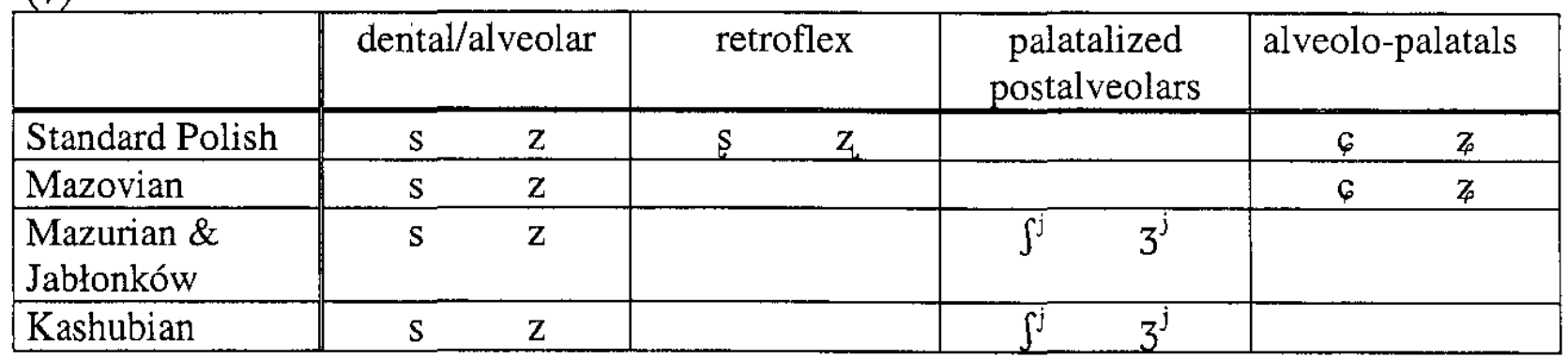

The inventories in (7) show that (i) alveolar sibilants are present in every system, (ii) retroflexes are not included in two-sibilant systems, and (iii) two contrasts are not attested: $\int$ vs. 6 and $\int^{j}$ vs. 6 . Instead, either palatalized postalveolars or alveolo-palatals contrast with dentals/alveolars. We might speculate on why this is the case. As far as (i) is concerned, the most common fricative that occurs in languages of the world is s. In UPSD inventory 196 languages out of 451 contain a voiceless alveolar sibilant fricative $s$ and 42 languages a voiceless dental sibilant fricative ss. 135 languages are reported to have some kind of s-sound which can be dental or alveolar. By contrast, $\int$, the second most common sibilant is present in 187 languages out of 451, cf. Maddieson \& Precota (1992). In other words, the relation between (dental and alveolar) $s$ and $\int$ is 373 vs. 187 in 451 languages. Hence, Polish dialects are not an exception regarding the universal preference which is most probably motivated perceptually because $s$ displays the greatest acoustic energy, see e.g. Maddieson (1984: 4952) and the results of COG measurement presented in section 4 for discussion.

s Mazurian is spoken in the northeastern regions of Poland (near Malbork, Ostróda, Lubawa and eastern Warmia) and Jabłonków dialects cover the small area in the southern part of Poland around Jabłonków. 
Concerning (ii), retroflexes are cross-linguistically far from being common. In UPSID they are only attested in 23 languages. One possible reason could be that they are more difficult from an articulatory point of view than e.g. 6. Evidence confirming this assumption is that they are acquired by children later than 6 and even $s$. As was shown by Eobacz (1996), Polish children pronounce the alveolo-palatal sounds considerably earlier than retroflexes. Adults talking to children replace retroflexes with alveolo-palatals, e.g., instead of $\left.\widetilde{t_{s}}\right]$ ego

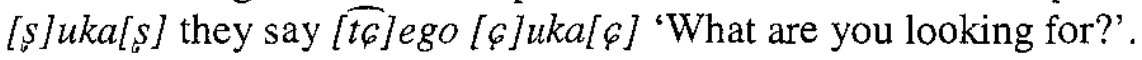

Another possible reason why retroflexes are avoided in dialects is that in comparison to alveolo-palatals the latter play a much more important role in Polish morphology than the former. For example, there are phonological rules that convert $/ \mathrm{s} /$ to $[\varphi]$ or $/ \mathrm{t} /$ to $\left[\mathrm{t}_{\varphi}\right]$ before front vowels,' cf. e.g., Rubach (1984), Szpyra (1995). Consequently, the alveolo-palatals appear in both nominal and verbal inflection, e.g., nos $+e$ no[6]e 'nose' nom./loc., plote ple[t居]esz 'to weave' 1.sg./2.pl.pres., cf. Stankiewicz (1986:109). This suggests that the loss of retroflexes does not affect Polish morphology in a significant way.

The last question (iii) why contrasts such as $\int$ vs. 6 and $\int^{j}$ vs. 6 are not attested in Polish dialects is discussed in detail in section 4.

\subsection{Lower Sorbian}

Another Slavic language that displays a three way-phonemic sibilant distinction is Lower Sorbian. ${ }^{10}$ Its inventory is shown in (8). As in the case of other Slavic languages, different symbols are used in the literature on Lower Sorbian. For example, Stadnik (1998:385) and

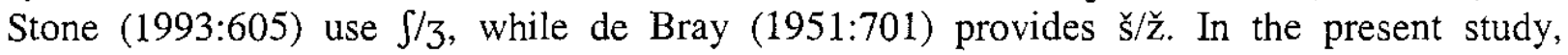
however, I argue that the Lower Sorbian sibilants are retroflexes, i.e. $S$ and $z_{\text {: }}$

(8) Lower Sorbian

\begin{tabular}{lllll} 
& dental & \multicolumn{2}{r}{ retroflex } & \multicolumn{2}{c}{ alveolo-palatal } \\
fricative & $\mathrm{s} z$ & $\frac{\mathrm{s}}{\mathrm{ts}}$ & $\frac{6}{\mathrm{t}}$ &
\end{tabular}

My claim that in Lower Sorbian there are retroflexes rather than postalveolars is primarily based on comparative evidence from Slavic languages. Discussing articulation of the corresponding sibilants of Upper Sorbian, Schuster-Šewc (1996:41) points to an exception. He notices that 'in the dialects of some villages north of Wojerecy (Hoyerswerda) and in all of Lower Sorbian š and ž are hard consonants.' Observations made by de Bray (1951) lead to similar conclusions. Analyzing the sibilants of the so-called Eastern dialect of Sorbian, spoken e.g. around Mužakov (Muskau), de Bray (1951:701) concludes that "š, ž are not soft, but also not hard as in Lower Lusatian and Polish; they therefore approach š and $\check{z}$ in Czech and Slovak". Taking into consideration the discussion on Polish in 2.1 (and also on Czech and Slovak in 2.6), this remark confirms the retroflexivity of the sibilants.

The comparison of the articulation between Upper and Lower Sorbian š, $\check{z}$ is unfortunately not as clear as the perceptive evidence. ${ }^{11}$ Describing the articulation of Upper Sorbian sibilants, Schuster-Šewc (1996:41) mentions that in the articulation of Lower Sorbian $\breve{s}, \breve{z}$ the constriction is produced between the anterior edge of the tongue and the alveoli and the dorsum of the tongue curves downward in the middle, thereby forming a concave channel

The same processes affect their voiced counterparts.

Lower Sorbian is spoken in the northern part of Lausatia centered around Chóśebuz (Cottbus).

"Unfortunately, I could not find a more detailed phonetic description or $\mathrm{x}$-ray tracings of Lower Sorbian sibilants. 
through which the expiratory air is released'. This is in contrast to the Upper Sorbian sibilants that are produced with the anterior part of the tongue approaching the palatum, cf. also the description in 2.8. Since it does not clearly follow what the anterior edge of the tongue is, the difference between the sound remains blurred.

A phonological argument in favor of the retroflexivity of Lower Sorbian sibilants is more evident than the articulatory one. De Bray (1951:701) notes that in contrast to the corresponding Upper Sorbian sibilants, cf. 2.8 , the Lower Sorbian $\breve{s} / \check{z}$ are followed by $y$ and not $i$, e.g. š[y]ja 'neck', $̌ z[y]$ to 'rye'. ${ }^{12}$

The interesting point about Lower Sorbian is that the alveolo-palatal affricates $\widetilde{t_{6}}$ and $\overline{\mathrm{d}} \mathrm{c}$ have merged with the alveolo-palatal fricatives 6 and $z{ }^{13}$ This shows that the three-way phonemic sibilant system in Lower Sorbian is - as in Polish dialects and other languages discussed below - not stable. The strategy adopted for avoidance of the complexity in Lower Sorbian is different than e.g. in Polish dialects. Whereas in Polish dialects places of articulation such as retroflex and alveolo-palatals have merged, in Lower Sorbian it is the manner of articulation that has fused.

In conclusion, the Lower Sorbian sibilant system confirms the claim that systems containing alveolo-palatals exhibit a certain inclination: retroflexes are preferred over postalveolars. It also shows another regularity, namely, the avoidance of sibilant complexity.

\subsection{Russian}

The next language to be discussed is Russian. In contrast to the languages examined above, alveolo-palatals do not exist in the Russian phonemic inventory. Instead, there are palatalized counterparts of dental and postalveolar fricatives. Consider the inventory given in (9).

fricative

affricate

$$
\begin{aligned}
& \text { dental retroflex postalveolar } \\
& \frac{s}{t s} \quad s^{j} \quad z^{j} \quad \frac{s}{t s} \quad z, \quad \int^{j} \int^{j}: \quad 3^{j}
\end{aligned}
$$

In light of the sibilant inventories presented above, we should pose the question of whether the sounds in question (traditionally transcribed as $̌$ ž and in (9) as $\mathbf{S}$ z) are postalveolars or retroflexes. Additionally, the lack of alveolo-palatals in Russian prompts the question of whether palatalized postalveolars have a similar influence as alveolo-palatals in Polish or Lower Sorbian.

Before addressing these issues, I consider first articulatory characteristics of the sounds in question. Recent phonetic studies, cf. Akishina \& Baranowskaja (1980), Bolla (1981), Keating $(1991,1993)$, have shown that the Russian sibilants š ž are produced with the tongue tip and show slight velarization. Keating $(1991,1993)$ categorizes them as retroflexes, while Ladefoged \& Maddieson (1996) call them flat postalveolar sibilants in order to distinguish them from, e.g., Tamil retroflexes where the tongue tip is significantly curled up. I call them flat retroflexes because (i) they are pronounced with the tongue tip and (ii) the tongue body is flat. The $\mathrm{x}$-ray tracing in (10) illustrates the articulation of this sibilant.

\footnotetext{
12 Note that $y$ is a front vowel, more retracted than i. It is also in contrast to $i$, a central vowel occurring in Polish or Russian.

13 They did not merge only in one context, i.e. if they come after a sibilant.
} 
(10) Russian s, cf. Bolla (1981:60)

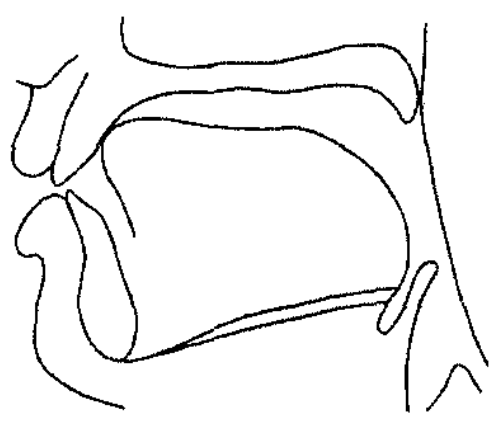

Keating (1991:35) points out an important distinction between retroflex plosives and retroflex fricatives of India which pertains to the curling of the tongue. While in the case of plosives, the tongue blade is extended out from the body of the tongue, with fricatives it is mostly not, which causes difficulty in distinguishing the tongue tip from the rest of the blade in X-ray tracings; for more examples see Hamann (2003:18ff). But the picture in (10) shows a clear articulation with the tongue tip that is even slightly curled up and touches the alveolar ridge. The retroflex character of this sound is particularly visible in (11), cf. Keating (1993:12) after Akishina \& Baranowskaja (1980). The shaded tongue shows the nonpalatalized fricative [š] while the non-shaded one displays its palatalized counterpart [ $\breve{s}^{\mathrm{s}}:$ ].

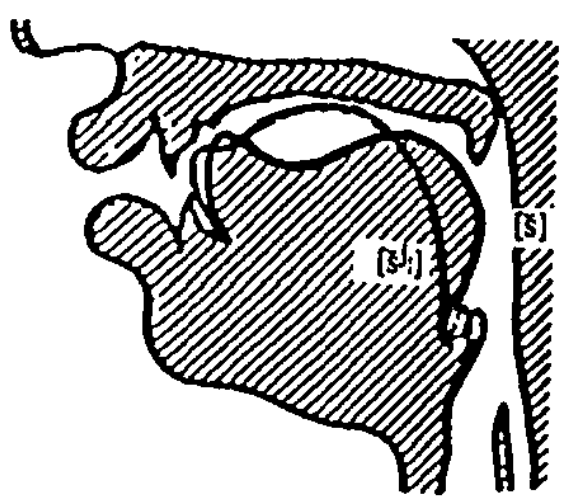

From a phonological point of view, the Russian s behaves in exact the same way as Polish s: it is not followed by high front vowels, cf. Hamann (2002a). Instead, the central vowel /i/ follows this sound. This provides additional phonological evidence fact that the sibilants under consideration ( $\mathrm{s} \mathrm{z}$ ) are retroflexes. Consider examples in (12).

(12) [şi]l 'he sewed'

[sì]na 'tire'

In sum, there is convincing phonetic and phonological evidence confirming the retroflex status of the Russian sibilants, traditionally represented as š $\check{z}$.

In light of these facts, the question arises why the system in (9) contains retroflex sounds. My own preliminary analysis of recordings of Russian has shown that Russian (long) palatalized postalveolars [ $\left.\int^{j}:\right]$ are very similar to alveolo-palatals from a perceptive point of view. Polish native speakers perceive them either as alveolo-palatals or as sounds which are very close to Polish alveolo-palatals. Pairs like the ones presented in (13) are almost indistinguishable. This observation leads to a preliminary conclusion that Modern Russian is 
undergoing important changes, namely, alveolo-palatals are emerging. For detailed phonetic measurements, cf. section 4 .

$$
\operatorname{bor}\left[\int^{\mathrm{j}}:\right] \rightarrow \text { bor[c] 'borsh' nom.sg. } \quad \operatorname{vra}\left[\mathrm{tf}^{\mathrm{j}}\right] \rightarrow \operatorname{vra}[\mathrm{tc}] \quad \text { 'doctor' nom.sg. }
$$

Important for the discussion on the development of retroflexes in Russian are the variants of palatalized plosives, $\mathrm{t}$ and $\mathrm{d}^{\mathrm{j}}$. Sawicka (2001:11) makes the observation that in Russian ' $\mathrm{t}$, $\mathrm{d}^{\mathrm{j}}$ are frequently accompanied by affricatization' which according to my impressionistic view is that they sound almost as Polish $\widehat{t} \bar{c} / \overline{\mathrm{d}}$, respectively. Jones \& Ward $(1969: 104)$ report that in the case of palatalized dental plosives 'a very short fricative element is heard' which is to be interpreted that after a plosive the fricative release is perceived. This change is rather unsurprising if one considers the emergence of alveolo-palatals (i.e., [+ant] $\rightarrow[$-ant]) from the diachronic point of view. In Polish and other Slavic languages, the alveolo-palatals have emerged as a consequence of the palatalization of anterior plosives, i.e., from $\mathrm{t}^{\mathrm{j}}$ and $\mathrm{d}^{\mathrm{j}}$, cf. Carlton (1991), Rochon (2000). It is important to keep in mind that in Protoslavic only dental/alveolars $(s, z)$ and postalveolars $\left(\int 3\right)$ were attested. The palatalization of plosives $\left(\mathrm{t}^{\mathrm{j}}\right.$, $\left.\mathrm{d}^{\mathrm{j}}\right)$ and fricatives $\left(\mathrm{s}^{\mathrm{j}}, \mathrm{z}^{\mathrm{j}}\right)$ resulted in alveolo-palatal affricates and fricatives, respectively, cf. Rochon (2000). This change had, as I argue in the study, an important consequence, namely a shift from postalveolars to (flat) retroflexes.

\subsection{Ukrainian}

Ukrainian displays an even richer sibilant inventory than Russian (and Belorussian discussed below). However, there is no consensus concerning its phonemic inventory including sibilants. The core of the problem lies in the fact that it is difficult to define Standard Ukrainian. Zilyns'skyj (1979:30) mentiones two predominat types of received speech, i.e. western pronunciation (Galician or L'viv pronunciation) and eastern pronunciation (the Dnieper region or Kievan-Poltavan). Both pronunciation types differ with respect to sibilant systems and therefore will be discussed separately. ${ }^{14}$ In addition Transcarpathian dialects will be analyzed because they show important regularities with respect to the perceptual motivation of the presence of retroflexes.

Although the sibilant systems presented below are mainly based on Zilyns'skyj's study, the symbols I use are different from his for at least two reasons. First, they are adjusted to the phonetic convention adopted in the present study (mainly IPA symbols). Secondly, a difference is made between retroflexes and postalveolars, i.e., š ž appear either as retroflexes s $z_{\text {o }}$ or postalveolars $\int 3$ according to the phonetic (and phonological) descriptions of the sounds given by Zilyns'kyj. The main features of the descriptions will be provided and discussed.

In (14) the sibilant system of the western group of Ukrainan dialects is shown.

(14) The western group

\begin{tabular}{llllll}
\multicolumn{3}{c}{ dental } & \multicolumn{2}{c}{ retroflex } & alveolo-palatals \\
fricative & $\mathrm{s}$ & $\mathrm{z}$ & $\mathrm{s}$ & $\mathrm{z}$ & $\varphi\left(\mathrm{s}^{\mathrm{j}}\right) \mathrm{z}\left(\mathrm{z}^{\mathrm{j}}\right)$ \\
affricate & $\frac{\mathrm{ts}}{\mathrm{dz}}$ & $\frac{6}{\mathrm{t}}$ & $\frac{\mathrm{dz}}{\mathrm{dz}}$ & $\mathrm{t}\left(\widetilde{\mathrm{ts}}^{\mathrm{j}}\right) \mathrm{d} \mathrm{d}(\overline{\mathrm{dz}})$
\end{tabular}

14 In Zilyns'kyj's study, which I mainly follow in my analysis, four dialect groups for Ukrainian are propsed. This division is purely geographical.

- the Northern Archaic Group: dialects of Polissja and Pidljašša,

- the Southern Archaic Group: Carpathian dialects,

- the Eastern Group: eastern dialect, dialects of the Dnieper area,

- the Western Group: southern Volhynia, the southwestern Kievan area, Podillja, Bessarabia, northern Bukovina, eastern Galicia (mountain dialects excluded) and the southern Xolm area. 
Although Zilyns'kyj calls the sibilants š ž alveolars, I present them in (14) as retroflexes (s, z) because "the constriction is formed by the raised tip of the tongue" Zilyns'kyj (1979:107). This description considerably differs from that of the corresponding sibilants of the eastern group, where $\breve{s} \check{z}$ are not pronounced with the tongue tip but the tongue blade, cf. discussion below. As far as the alveolo-palatals in (14) are concerned, they are optionally realized as 'nearly' alveolo-palatals, i.e. as strongly palatalized $s^{j}$ and $z^{j} .{ }^{15}$ However, in individual pronunciation and occasionally in some eastern Galician dialects, alveolo-palatals are realized as palatalized postalveolars $\int^{\mathrm{j}} 3^{\mathrm{j}}$, cf. Zilyns'kyj (1979:111).

The next major group constituting Ukrainian is the so-called Eastern group. Its sibilant system significantly differs from that of Western group. In (15) its inventory is presented.

(15) The eastern group

\section{dental}

fricative

affricate

$\frac{s}{\mathrm{ts}} \quad \frac{\mathrm{z}}{\mathrm{dz}} \quad \frac{\mathrm{s}^{j}}{\mathrm{ts}^{j}} \quad \frac{z^{j}}{\mathrm{dz}^{j}}$

$$
\begin{aligned}
& \frac{\int}{\mathrm{t} j} \frac{3}{\mathrm{~d} z} \quad \frac{\int^{j}}{\mathrm{t} \int^{j}} \frac{3^{j}}{\mathrm{~d}^{j}}
\end{aligned}
$$

In eastern Ukrainian dialects š ž are reported to be pronounced by a somewhat higher 'tonality' than in western received pronunciation, cf. Zilyns'kyj (1979:108). The term 'tonality' refers to softness of the sibilants and lower tonality indicates their hardness. However, the sounds cannot be classified as the same as occurring in the southwestern dialects. Their higher tonality as well as the phonetic description of the articulation according to which they are pronounced by the tongue blade strongly suggest that they are postalveolars, i.e., $\int 3$ in IPA terms. It is also important to stress that the sounds $s^{j}$ and $z^{j}$ are only lightly palatalized in comparison to the optional $\mathrm{s}^{j}$ and $\mathrm{z}^{\mathrm{j}}$ occurring in western dialects. This indicates that from the acoustic/perceptual point of view they evidently diverge from alveolopalatals.

The last group of Ukrainian dialects relevant for the present discussion is Transcarpathian, whose sibilant system is presented in (16).

\begin{tabular}{|c|c|c|c|c|c|c|c|c|}
\hline \multicolumn{4}{|c|}{ dental } & \multicolumn{3}{|c|}{ retroflex } & \multicolumn{2}{|c|}{ alveolo-palatals ${ }^{16}$} \\
\hline fricative & $S$ & $\mathrm{Z}$ & $s^{j}$ & $z^{j}$ & $S$ & $\mathrm{z}$ & 6 & $z$ \\
\hline affricate & $\widetilde{\text { ts }}$ & $\overline{\mathrm{dz}}$ & $\mathrm{ts}^{\mathrm{j}}$ & $\overline{\mathrm{dz}}^{\mathrm{j}}$ & tș & $\mathrm{dz}$ & $\overline{t_{6}}$ & $\overline{d z}$ \\
\hline
\end{tabular}

(16) Transcarpathian

Zilyns'kyj (1979:107) mentions that in western Transcarpathian dialects (and the dialects of the Sjan River Basin) the fricatives š ž have an even lower 'tone' than in western dialects which suggest a classification of the sounds as retroflexes from the perceptual point of view. Furthermore, they are also pronounced with protruded lips which contribute to the lowering of the tonality by increasing the resonator size. ${ }^{17}$ In addition, the description of their articulation ${ }^{18}$ also reveals their retroflex nature because they are articulated with the tongue tip and their place of articulation is "at the junction of the upper gums and the hard palate or even further back" Zilyns'kyj (1979:108). The retroflexivity of these sounds is also confirmed by a

15 One of the extralinguistic reasons for this distribution could be that the southwestern Ukraine belonged to Poland before the second world war. Polish people have been lived there and most probably influenced the Ukrainian dialects. It is worth mentioning that alveolo-palatals are found only in this group of dialects.

16 In some western dialects of this group $6 \quad z$ are consistently replaced by $\int^{j} 3^{j}$, e.g. [ $\left.\int^{j}\right]$ vit instead of [c]vit, cf. Zilyns'kyj (1979:111).

17 Zilyns'kyj (1979:109) also mentions that $s ̌ z$ are articulated with protruded lips in different eastern and western dialects, although to a different degree. He does not discuss this point in detail.

18 Unfortunately, Zilyns'kyj (1979) does not provide an accurate picture of the articulation of the sounds. 
phonological argument, similarily to Polish, Lower Sorbian and Russian. In the context of the following $/ \mathrm{i} /$, this vowel is retracted and pronunced as [i]. Consider examples in (17), cf. Carlton $(1991: 288,340)$. Note that $\mathrm{i}(и)$ is still present in the orthography.

$$
\begin{aligned}
& \text { шить } \breve{s}[\mathrm{i}] \mathrm{t}^{\mathrm{j}} \quad \text { 'to sew' nom.sg. } \\
& \text { жито ž[i] to 'rye' nom.sg. }
\end{aligned}
$$

In sum, Ukrainian dialects show that retroflex sibilants occur in inventories where there are alveolo-palatals (western pronunciation and Transcarpathian dialects), while their presence is not available in inventories where postalveolars (and palatalized postalveolars) are attested, cf. Eastern pronunciation.

\subsection{Serbian and Croatian}

The sibilant system of Serbian and Croatian is shown in (18).

\begin{tabular}{|c|c|c|c|c|c|}
\hline & alveolar & postalve & /ret & flex & alveolo-palatal \\
\hline fricative & $S \quad z$ & $\int 3$ & S & z & $\left(\begin{array}{ll}6 & 7\end{array}\right)^{19}$ \\
\hline affricate & $\overline{\mathrm{ts}} \widehat{\mathrm{dz}}$ & $\overline{\mathrm{tj}}$ & $\overparen{\mathrm{ts}}$ & $\mathrm{dz}$ & $\overline{t 6}$ \\
\hline
\end{tabular}

(18) Serbian and Croatian

It has to be stressed that the retroflex character of the sibilants $s z_{\text {}}$ is not commonly recognized in the literature on Serbian and Croatian. In an overwhelming number of studies they are assumed to be postalveolars (and transcribed as š ž or $\int 3$ ), cf. Kordić (1997), Stadnik (1998), Stankiewicz (1986). In (18) I added both postalveolars and retroflexes for reasons discussed below. They are in complementary distribution: either the former or the latter are present.

An inspection of the sibilants commonly transcribed as $\check{s} / \check{z}$ or $\int / 3$ reveals that these sounds significantly diverge from postalveolars. Compare the $\mathrm{x}$-ray tracing of the Serbian sibilant s in (19) with that of Bulgarian shown in (2b).

(19) Serbian $s$, cf. Keating (1991:35) after Miletič (1960).

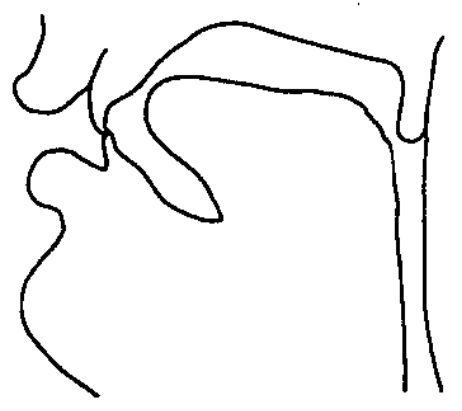

The main difference between Serbian $\mathbf{s}$ and Bulgarian $\int$ is that the former is articulated with the tongue tip and the latter with the tongue blade. Furthermore, the tongue body is flat in Serbian s, whereas it is domed in the Bulgarian sibilant. In addition, in the articulation of Serbian $s$ the tongue blade is moved up and back and touches the edge of the alveolar ridge, cf. Keating (1991:35). Keating also observes that Slavic languages (without specifying which ones) show 'a somewhat different kind of retroflex fricative' than, e.g., in Tamil, an opinion, which is also shared by Ladefoged \& Maddieson (1996). The difference between the

${ }_{19}$ The reason 6 and $z$ are parenthesized is that their occurrence is limited to certain dialects which will be discussed below. 
retroflexes in these languages is that in Serbian the tongue tip is not curled up very high and the underside of the blade is not directly used. What is typical for this sound is that the tongue tip is raised slightly so that it touches the alveolar ridge, as shown in (19). There is also a considerable similarity between the Serbian and the Polish retroflex fricatives in terms of articulation, cf. (2a). ${ }^{20}$ In addition, Keating (1991:35) observes that retroflex fricatives in Slavic languages, which are often transcribed as postalveolars, "sound more like other retroflexes".

As far as alveolo-palatal fricatives are concerned, they have disappeared in the majority of Serbian and Croatian dialects. In many sources they are not included in their phonemic systems at all, cf. Leskien (1976:34), Rehder (1991: 49), Browne (1993:310). But, as will be shown in (20), they show up in few dialects, i.e. only in Eastern Herzegovina, ZetaLovćen and some areas of Slavonia, cf. Ivić (1958), Stankiewicz (1986:107). Alveolo-palatal affricates, on the other hand, are reported to change to retroflexes (or postalveolars). According to Stankiewicz (1986:107) the latter development takes place in western štokavian (Istria, southern Italy, northern Dalmatia, Dubrovik, Boka Kotorska), among the Muslims of Bosnia and Herzegovina, among the Catholics of eastern and northern Slavonia, in some areas of Banat and in Timok-Lužnik. Some peripheral štokavian ${ }^{21}$ dialects (like čakavian, southwestern kajkavian, and western Slovenian) preserve the distinction alveolo-palatal vs. retroflex, while others change to '[ts]akavism' where postalveolars/retroflexes merge with $s$ sounds, cf. also (20j). This diversity of sibilant inventories reveals that it is almost impossible to analyze a sibilant system of Serbian and Croatian because such a system does not exist. ${ }^{22}$ It is rather the case that various dialects should be taken into consideration. This variety is especially observable in štokavian dialects which sibilant systems are summarized in (20). The symbols used in (20) for describing postalveolar/retroflex fricatives and affricates are not adjusted to the IPA convention but reflect the symbols used in the source i.e. Ivic (1958). ${ }^{23}$ This is motivated by the fact that there is not enough evidence available to decide whether sibilants from a particular dialect are indeed retroflexes or postalveolars. In addition, it should be stressed that phonemic inventories and pronunciation varieties are tightly connected with religion. Therefore the description of the dialects in (20) is often referred not only to a geographical area but to Catholic, Orthodox or Muslim.

\begin{tabular}{|c|c|c|c|c|c|c|c|}
\hline Dialect name & \multicolumn{2}{|c|}{ dental/alveolar } & \multicolumn{2}{|c|}{$\begin{array}{l}\text { postalveolar/ } \\
\text { retroflex }\end{array}$} & \multicolumn{2}{|c|}{ Alveolo-palatal } & Source \\
\hline $\begin{array}{l}\text { a. Eastern Hercegovina (jekavian } \\
\text { dialect among Orthodox people) }\end{array}$ & $\frac{s}{\text { ts }}$ & $\mathrm{z}$ & & $\frac{\check{\mathrm{z}}}{\mathrm{dž}}$ & & $\frac{\mathrm{z}}{\mathrm{d} z}$ & Ivić $(1958: 141)$ \\
\hline $\begin{array}{l}\text { b. Bosnia and Herzegovina } \\
\text { dialects (among Moslems) }\end{array}$ & $\frac{s}{\text { ts }}$ & $\mathrm{z}$ & & $\frac{\mathrm{z}}{\mathrm{d} \check{\mathrm{z}}}$ & & & Ivić (1958:141) \\
\hline $\begin{array}{l}\text { c. Šmadija-Vojvodina } \\
\text { (štokavian dialects spoken in } \\
\text { northern and northwestern parts of } \\
\text { Serbia) }\end{array}$ & $\frac{s}{\text { ts }}$ & $\frac{\mathrm{z}}{\mathrm{dz}}$ & & $\frac{\check{z}}{\mathrm{dž}}$ & & & Ivić (1958:179) \\
\hline
\end{tabular}

20 Note that the Serbian sibilant as shown in (19) is very similar to the Polish fricative illustrated in (2a), cf. Wierzchowska (1980:64).

21 Generally, they are divided into ekavian, jekavian and ikavian dialects depending on the on the realization of e, i.e., $\mathrm{e} \rightarrow \mathrm{e}$ in ekavian, $\mathrm{e} \rightarrow$ (i)je in jekavian, and $\mathrm{e} \rightarrow \mathrm{i}$ in ikavian dialects.

22 For the historical background, cf. Carlton (1991:333), Rehder (1991:56-60).

23 The only difference between the symbols in (20) and Ivić (1958) is that the affricates are reflected as tš dž in the former and as $c$ and $\breve{3}$ in the latter. 


\begin{tabular}{|c|c|c|c|c|c|c|c|}
\hline $\begin{array}{l}\text { d. Young ikavian dialect spoken } \\
\text { among catholics }\end{array}$ & $\frac{\mathrm{s}}{\mathrm{ts}}$ & $\mathrm{z}$ & $\frac{\check{s}}{\mathrm{ts̆}}$ & $\frac{\check{\mathrm{z}}}{\mathrm{dz}}$ & $\overline{16}$ & $\overline{\mathrm{d} z}$ & Ivić (1958:190) \\
\hline $\begin{array}{l}\text { e. Young ikavian dialect spoken } \\
\text { among Moslems }\end{array}$ & $\frac{\mathrm{s}}{\mathrm{ts}}$ & $\mathrm{z}$ & $\frac{\check{s}}{\mathrm{tšs}}$ & $\frac{\check{z}}{\mathrm{~d} z \grave{z}}$ & & & Ivić (1958:190) \\
\hline f. Zeta-Lovćen dialect & $\frac{\mathrm{s}}{\mathrm{ts}}$ & $\frac{z}{d z}$ & $\check{\mathrm{s}}$ & $\overline{\mathrm{z}} \overline{\mathrm{dž}}$ & $\frac{6}{16}$ & $\frac{\mathrm{z}}{\mathrm{d} z}$ & Ivić (1958:211) \\
\hline g. Kosovo- Resava main dialects & $\frac{s}{\text { ts }}$ & $\overline{\mathrm{z}}(\overline{\mathrm{dz}})$ & $\check{\text { ťs }}$ & $\frac{\check{z}}{\mathrm{dž}}$ & $\overparen{\mathrm{t} \varphi}$ & $\widehat{\mathrm{dz}}$ & Ivić (1958:233) \\
\hline $\begin{array}{l}\text { h. Kosovo- Resava periphere } \\
\text { dialects }\end{array}$ & $\frac{\mathrm{s}}{\mathrm{ts}}$ & $(\overline{\mathrm{d} z})$ & ťs & $\frac{\check{z}}{\mathrm{džz}}$ & & & Ivić (1958:233) \\
\hline i. Istrian ikavian dialects & $\frac{s}{\text { ts }}$ & $\mathrm{z}$ & $\frac{\check{s}}{\text { tšs }}$ & $\check{Z}$ & & & Ivić $(1958: 255)$ \\
\hline $\begin{array}{l}\text { j. Istrian ikavian dialect (north- } \\
\text { western part of westistrian zone) }\end{array}$ & $\frac{s}{\mathrm{ts}}$ & $\mathrm{z}$ & & & & & Ivić (1958:255) \\
\hline $\begin{array}{l}\text { h. dialects of Rekaš und Banatska } \\
\text { Crna Gora }\end{array}$ & $\frac{s}{\mathrm{ts}}$ & $\frac{\mathrm{z}}{\mathrm{d} z}$ & $\frac{\check{s}}{\mathrm{tšs}}$ & $\frac{\check{z}}{d z ̌ z}$ & $\overline{t 6}$ & $\overline{\mathrm{d} z}$ & Ivić (1958:276) \\
\hline i. Gallipoli dialect & $\frac{\mathrm{s}}{\mathrm{ts}}$ & $\frac{\mathrm{z}}{\mathrm{dz}}$ & & & $\overline{\mathrm{t} 6}$ & $\overline{d z}$ & Ivić (1958:276) \\
\hline $\begin{array}{l}\text { j. Slavonian dialects: partly } \\
\text { jekavian dialects }\end{array}$ & $\frac{s}{\text { ts }}$ & $\bar{z}$ & $\check{\text { ťs }}$ & $\frac{\check{z}}{\mathrm{~d} \check{z}}$ & & $\frac{z}{d z}$ & Ivić (1958:296) \\
\hline $\begin{array}{l}\text { k. Slavonian dialects: northeastern } \\
\text { part of the southern zone, some } \\
\text { dialects in the northern part }\end{array}$ & $\frac{s}{\mathrm{ts}}$ & $z$ & $\frac{\check{s}}{\mathrm{tšs}}$ & $\frac{\check{z}}{d z ̌}$ & & & Ivić $(1958: 296)$ \\
\hline $\begin{array}{l}\text { 1. remaining Slavonian dialects; } \\
\text { different from those descibed in } \mathrm{j} \\
\text { and } \mathrm{k} \text {. }\end{array}$ & $\frac{\mathrm{s}}{\mathrm{ts}}$ & $z$ & $\frac{\breve{s}}{\mathrm{ts̆}}$ & $\frac{\check{z}}{\mathrm{~d} z \grave{z}}$ & $\overline{16}$ & $\widetilde{\mathrm{d} z}$ & Ivić (1958:296) \\
\hline
\end{tabular}

The table in (20) is by no means complete because it does not include all štokavian dialects and all variants within a single dialect. There are also other pronunciation variants than those presented in the table. For example, Ivić (1958:141) points out that in Bosnia and Herzegovina dialects, cf.(20b), the disappearance of alveolo-palatal affricates resulted in different pronunciation types of the postalveolar affricates which can be realized either as alveolo-palatals or as palatalized postalveolars.

In light of the facts it seems to be obvious that it is not correct to talk about retroflexes of Serbian and Croatian but rather about (non)retroflexes of separate dialects. Therefore, we can only speculate that the retroflex sibilant shown in (19) belongs to the sibilant inventory of one of the štokavian dialects where alveolo-palatals are still present. In any case, the retroflex sibilant cannot be representative for Serbian and Croatian.

This doubt is also augmented by considering a phonological argument. In contrast to Lower Sorbian, Polish, and Russian the corresponding sibilants in Serbian and Croatian dialects are followed by i, e.g. lëpš[i] 'better', drž[i]m 'we are holding', cf. Rehder (1991:51f.). In addition, Leskien (1976: 88) notices that the sibilants under question, i.e., š and $\check{z}$ in his transcription, correspond to soft Protoslavic š' and ž', i.e. $\int, 3$ or $\int^{j}, 3^{j}$ in IPA terms. Stojkov (1955:81) observes that Bulgarian sibilants do not sound like their Russian and Polish counterparts, but rather as their eqivalent Czech, Slovak and Serbian/Croatian sounds, i.e. as $\int, 3$. 
In summary, it is almost impossible to draw conclusions about a unified sibilant system of Serbian and Croatian. Consequently, every single dialect has to be analyzed separately. The seemingly contradictory evidence, e.g. the retroflex in (19) vs. the nonretroflexivity of the the corresponding sound from a perceptual or phonological point of view, can be explained by the fact that it comes from a different dialect. On the other hand, there is too little evidence of single dialects available to draw reliable conclusions. ${ }^{24}$

What the Serbian and Croatian dialects show is an evident lack of stability of complex sibilant systems. They also do not refute the fact that retroflex sibilants are present in systems containing alveolo-palatals. The latter point, as stressed above, requires further investigation.

\subsection{Czech and Slovak}

Czech and Slovak sibilant inventories form a group of Slavic languages with relatively simple sibilant inventories, i.e. two-way place systems. In contrast to three-way sibilant systems, as discussed above, they do not contain retroflexes in their inventories.

In the following, articulatory, perceptive and phonological evidence will be provided confirming the fact that the sibilants under consideration are postalveolars (and not retroflexes) and in section 4 acoustic motivation for the two-sibilant systems will be considered.

Czech and Slovak contain alveolar and postalveolar sibilants with the only difference being that the voiced affricate $\overline{\mathrm{d} z}$ is not present in the Czech system. The inventories of both languages are presented in (21).

a. Czech, cf. Kučera (1961:24)

\begin{tabular}{|c|c|c|c|c|}
\hline \multirow{3}{*}{$\begin{array}{l}\text { fricative } \\
\text { affricate }\end{array}$} & \multicolumn{2}{|c|}{ alveolar } & \multicolumn{2}{|c|}{ postalveolar } \\
\hline & s & $\mathrm{z}$ & $\int$ & 3 \\
\hline & $\widehat{\mathrm{ts}}$ & & $\overline{\mathrm{tj}}$ & \\
\hline \multicolumn{5}{|c|}{ b. Slovak, cf. Rubach (1993:31) } \\
\hline & \multicolumn{2}{|c|}{ alveolar } & \multicolumn{2}{|c|}{ postalveolar } \\
\hline fricative & s & $z$ & $\int$ & 3 \\
\hline affricate & ts & $\overline{\mathrm{dz}}$ & $\overline{\mathrm{t} f}$ & $\overparen{d_{3}}$ \\
\hline
\end{tabular}

As far as the articulation of the postalveolar fricatives is concerned, they share important articulatory gestures which are distinct from their Polish and Russian counterparts $\$$ and $z$ : This is illustrated by the X-ray frames of Czech and Slovak $\int$ in(22a) and(22b), respectively.

(22) a. Czech, cf. Palkovà (1994:229)

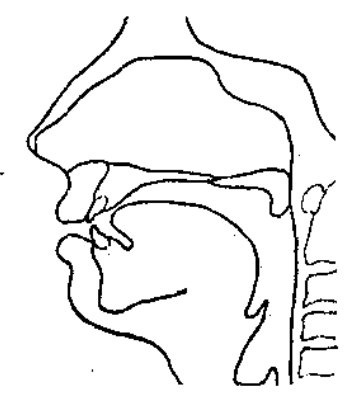

b. Slovak, cf. Pauliny et al. (1968:84)

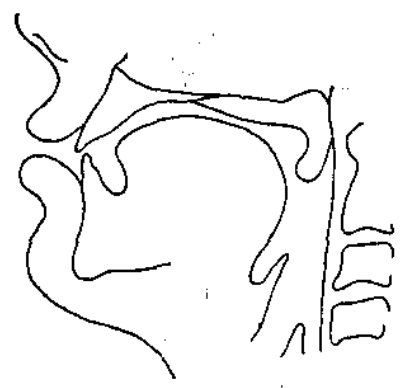

\footnotetext{
I was not able to find any $x$-ray tracings of sibilants attested in single dialects.
} 
Although the tongue body in Czech is not as domed as in Slovak ${ }^{25}$ the important difference between Czech/Slovak and Russian/Polish is illustrated in (22). It concerns the primary articulator: while in Czech and Slovak it is the tongue blade, in Polish and Russian it is the tongue tip. In the latter case the tongue body is also flat and velarized, whereas in the former it is raised without any velarization gesture.

The phonetic evidence that Czech and Slovak sibilants are postalveolars, i.e. $\int 3$, is supported with a phonological argument. If the sibilants are indeed not retroflex, we would expect that they behave differently from the corresponding sounds in Polish and Russian. They would be expected to occur in a pre-i context, which is indeed confirmed by the data, cf. (23).

a. Czech, cf. Trávníček (1951:40)

$\begin{array}{lll}\text { duši } & \text { du[ji] } & \text { 'soul' sg.gen. } \\ \text { noži } & \text { no[3i] } & \text { 'leg' sg.pl. }\end{array}$

b. Slovak, cf. Rubach $(1993: 34,119)$

$\begin{array}{lll}\text { žiab } & {[3 \mathrm{i}] \mathrm{ab}} & \text { 'frog' gen.pl } \\ \text { šibat' } & {[\text { [ji]bat' }} & \text { 'to beat' }\end{array}$

Finally, it has also been observed that Czech $\int$ and 3 differ from the corresponding Polish sounds in a sense that the former sounds are 'softer' than the latter ones. Lehr-Spławiński (1957:93) stresses that especially Czech $\widehat{\mathrm{t} \int}$ is considerably softer than the Polish $\widehat{\mathrm{ts}} .{ }^{26} \mathrm{As}$ far as $\int$ and 3 are concerned, they also sound softer than the Polish sounds, cf. Lehr-Spławiński (1957:99). Stojkov (1955:81) observes that Czech and Slovak š and ž differ from the corresponding Russian and Polish sibilants. Similarly, de Bray (1951:74), makes an observation, cited in 2.2 , that Czech and Slovak š and ž are not as 'hard' as the corresponding sibilants in Polish and Lower Sorbian.

Apart from these facts, there is also minor evidence suggesting a retroflex character of Czech fricative sibilants. Lehr-Spławiński (1957:99) notes that the 'hard' pronunciation of the Czech sibilants is also attested. Skaličková (1974:104), comparing English and Czech $\int$, provides an $\mathrm{x}$-ray tracing suggesting retroflexivity of this sound. But if Czech $\int$ were indeed retroflex, then it should be considered as an exception from a broader perspective. I am rather reluctant to assume its retroflex character because there would be a serious violation of crosslinguistic preferences. First, the retroflex would be followed by i, second, it would have a rather odd and not related to other Slavic languages two-phonemic sibilant inventory consisting of an alveolar and retroflex sibilant. Third, it would sound softer than Polish and Russian sibilants. For these reasons $\mathrm{I}$ assume that $\mathrm{Czech}$ sibilant fricatives are not retroflex leaving aside confusing articulatory evidence present in the literature. I also assume that the retroflexivity of this sound could be sporadically attested, especially in areas closed to Poland. My conclusion differs from Hamann's (2002b) who states that the status of the sibilant in question is not clear.

In sum, both articulatory and phonological evidence show that the sibilants in Czech and Slovak are postalveolars $\int$ and 3 , and not retroflexes as in Polish, Russian or Lower Sorbian.

\footnotetext{
25 Note that both pictures come from different sources.

26 This observation is not equivalent to the difference between e.g. the hard $t, d$ and the soft $t^{j}, d^{j}$ opposition because there is no phonemic relevance for the softness of Czech $\int$, cf. Lehr-Spławiński (1957:93).
} 


\subsection{Bulgarian}

A parallel situation can be observed in Bulgarian. The sibilant inventory in that language shows the alveolar vs. postalveolar contrast, as in (24), cf. Scatton (1993:191). Some inventories of Bulgarian also include $\overline{\mathrm{dz}}$ and $\overline{\mathrm{dz}}^{\mathrm{j}}$, cf. Hill (1993:21). However, $\overline{\mathrm{dz}}^{\mathrm{j}}$ occurs only in foreign proper names, e.g. Já[ $\overline{d z}$ j]a from Polish Ja[ $\overline{d z}]$ a 'fem.proper name, nom.sg.' . As far as $\overline{d z}$ is concerned, it is found in dialectal words which are replaced by $z$ in the literary language $[\overline{d z}]$ viezda $\rightarrow[z]$ viezda 'star'.

(24) Bulgarian

\begin{tabular}{lllll} 
& \multicolumn{2}{c}{ alveolar } & \multicolumn{1}{c}{ postalveolar } \\
fricative & $\frac{\mathrm{s}}{\mathrm{ts}}$ & $\frac{\mathrm{s}^{j}}{\mathrm{ts}} \mathrm{z}^{\mathrm{j}}$ & $\frac{\int}{\mathrm{t} \int}$ & $\frac{3}{\mathrm{~d} 3}$
\end{tabular}

The Bulgarian fricative $\int$ shows clear phonetic and phonological differences from the equivalent Polish and Russian sounds. The tongue shape in Bulgarian $\int$ is 'domed' and the front tongue body is raised as shown in (25).

(25) Bulgarian $\int$, cf. Stojkov (1955:81)

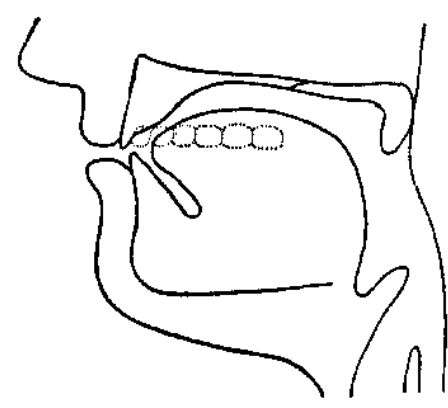

Phonologically, Bulgarian $\int$ occurs in a pre-i context, e.g., ti[fi]na 'silence', cf. Hamann (2002a), which confirms that it is not retroflex. Stojkov (1955:81) makes also an observation that "Bulgarian $ш$ and $ж^{27}$ sound as $\amalg$ and $ж$ in Czech, Slovak and Serbo-Croatian, but they differ from Russian and Polish [...]". This remark also suggests that these Bulgarian sibilants should be classified as postalveolars.

The Bulgarian sibilant system shows an important regularity, i.e. in two-way sibilant systems, postalveolars are present instead of retroflexes. Additionally, the Bulgarian system reveals that palatalized alveolars do not have the same influence as alveolo-palatals do on sibilant systems, i.e. postalveolars do not change to retroflexes.

\subsection{Upper Sorbian}

Upper Sorbian is another example of a language with a two-way sibilant contrast. Interestingly, Upper Sorbian evidently differs from Lower Sorbian, as far as the sibilant inventory is concerned, cf. 2.2. Consider the inventory shown in (26), cf. Schuster-Šewc (1996:22).

\section{Upper Sorbian}

$$
\text { dental postalveolar }
$$

$\begin{array}{llllll}\text { fricative } & s & z & \left(z^{j}\right) & \int & 3 \\ \text { affricate } & \overparen{t s} & (\overparen{d z}) & (\widehat{t s})^{j} & \frac{\mathrm{tj}}{d z}\end{array}$

$27 \quad \amalg$ and $*$ are letters for $\int 3$. 
Schuster-Šewc (1996:38) points out that the frequency of occurrence of $\overparen{\mathrm{dz}}, \widehat{t s}^{j}$ and $z^{j}$ is very low: $\widehat{\mathrm{ts}}^{\mathrm{j}}$ occurs in a few words, while the pronunciation of $\overline{\mathrm{dz}}$ is optional and in many cases replaced by $z$, e.g. in the declension of substantives ending in $-a$, e.g. Jadwi[ $\overline{\mathrm{dz}}] \mathrm{e}$ is pronounced as Jadwi[z]e. Therefore, all three sounds $\overparen{\mathrm{dz}}, \widehat{\mathrm{ts}}^{\mathrm{j}}$ and $\mathrm{z}^{\mathrm{j}}$ appear in brackets in (26).

The fact that there are postalveolars in Upper Sorbian and not retroflexes (as in Lower Sorbian) is confirmed phonologically: These sounds are followed by the high front vowel $i$, e.g. š[i]ć 'to sew', ž[i]wić so 'to live', cf. de Bray (1951:689). In addition, it is often stressed that Upper Sorbian $\int 3$ are 'soft' in comparison to the 'hard' Lower Sorbian s $z$, cf. e.g. de Bray (1951: 689), Schuster-Šewc (1996:41). As far as the articulation is concerned, it can be seen from an X-ray tracing of š and the description given in Schuster-Šewc (1996:40f.) that it is articulated with the tongue blade and a raised tongue dorsum, cf. (27).

(27) Upper Sorbian $\int$, cf. Schuster-Šewc (1996:41).

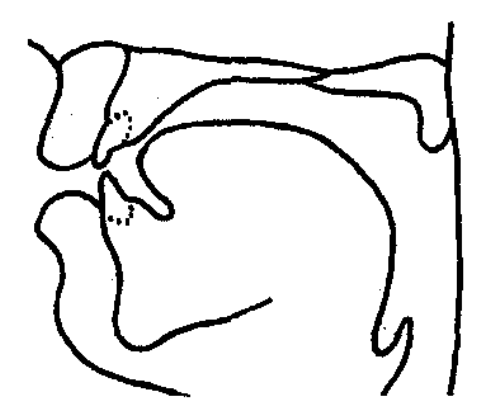

In sum, the system of Upper Sorbian consists of dental, palatalized dentals and postalveolar sibilants. It does not include retroflexes and therefore is an exemplification of the idea that retroflexes are marked sounds which presence is motivated by alveolo-palatals, not attested in Upper Sorbian. The latter case is well illustrated by a neighbouring language, i.e. Lower Sorbian, discussed in 2.2.

\subsection{Belorussian}

The Belorussian sibilant inventory is very similar to the Bulgarian one. It contains dental, palatalized dental and postalveolar sibilants, cf. (28).

(28) Belorussian, cf. Stadnik (1988: 382$)^{28}$

\begin{tabular}{|c|c|c|c|}
\hline & dental & & posta \\
\hline fricative & $\mathrm{s} \quad \mathrm{z}$ & $s^{j} \quad z^{j}$ & $\int(s)$ \\
\hline affricate & $\overparen{\mathrm{ts}} \widetilde{\mathrm{dz}}$ & $\overparen{\mathrm{ts}}^{\mathrm{j}} \widetilde{\mathrm{dz}}^{\mathrm{j}}$ & $\widetilde{\mathrm{ts}}(\widehat{\mathrm{ts}})$ \\
\hline
\end{tabular}

Although I have not found a detailed articulatory description of Belorussian postalveolars I place retroflexes in parentheses because I suspect that retroflexes - as opposed to postalveolars - are part of the Belorussian inventory, at least of some of its dialects. There are some arguments in favor of this claim. From a perceptual point of view, de Bray (1951: 132) describing Slavic languages, calls Belorussian sibilants 'hard' and distinguishes them e.g. from Bulgarian sibilants. The palatalization in Belorussian system especially with respect to $\mathrm{s}^{j}, \mathrm{z}^{\mathrm{j}}, \widetilde{\mathrm{ts}}^{\mathrm{j}}, \overline{\mathrm{dz}}^{\mathrm{j}}$ is strong, especially in the western part of Belorussian, i.e., palatalized sounds

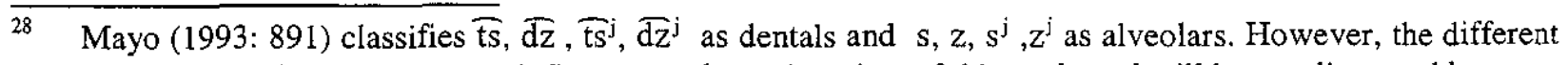
classification does not bear any influence on the main points of this study and will be not discussed here. 
Although I am not going into the diachronic development of sibilants in Slavic languages in detail here, it has to be stressed that Hall's observations on cooccurrence restrictions concerning $\int$ and 6 perfectly mirror the Slavic facts. Slavic sibilant systems do not violate this principle. They provide more cross-linguistic evidence for the claim that if a language is at stage /s $\int \mathrm{c} /$ it shows its instability in various ways. In some languages $\int$ shifts to $s$, as e.g. in Polish and Russian, and in other languages the alveolo-palatals merge with retroflexes or postalveolars, as e.g. in Serbian and Croatian dialects. In Lower Sorbian the alveolo-palatal affricates disappeared.

Although the explanation given by Hall (1997a) adequately describes the facts presented in 2, it is not clear for Slavic (and other) languages why it is e.g. $\int$ that changes and not $6 .{ }^{29}$ In the next section I will argue that the arrangement of sibilant inventories in Slavic languages is grounded acoustically/perceptually. I will also show that the changes sibilant systems undergo are not arbitrary but are rather motivated phonetically.

\section{Acoustic, perceptual and articulatory aspects of sibilant inventories}

The aim of this section is to provide acoustic/perceptual motivation for sibilant inventories. The results of the acoustic experiments presented below allow to answer the following questions:

a. Why are the systems $/ \mathrm{s} 6 \mathrm{~J} /$ and $/ \mathrm{s} \int^{\mathrm{j}} \mathrm{s} /$ not optimal?

b. Why is the system $/ \mathrm{s} 6 \mathrm{~s} /$ preferred to $/ \mathrm{s} 6 \mathrm{~J} /$ and $/ \mathrm{s} \int^{\mathrm{j}} \mathrm{s} /$ ?

c. Why does $\int / \int^{\mathrm{j}}$ change to $s$ in some inventories, while in others remains intact?

d. Why is it that $\int$ changes and not 6 ?

e. Why do palatalized dentals/alveolars change to alveolo-palatals?

f. Why do alveolo-palatals and not palatalized dentals/alveolars usually trigger the change from $\int$ to $s$ ?

Before discussing the experimental results and answering the questions in (33), I consider first the articulation of 6 in more detail. In contrast to $\int$ and $s$ which has been devoted much attention in section 2.1 , the articulation of 6 also requires an articulatory analysis for at least two reasons. First, it plays a significant role in shaping sibilant systems. Second, its articulatory characteristic is a reliable predictor of the distribution of the concentration noise, a factor of much importance for the present investigation.

The articulation of 6 , as occurring in Polish, will be discussed by comparing it to the articulation of Polish $s$ and Bulgarian $\int$. The X-ray frames of Polish $s$ and 6 shown in $(34 a, b)$, respectively, illustrate a clear articulatory difference between the sounds: while $s$ is produced with the tongue tip, 6 requires raising of the tongue blade toward the alveolar ridge.

29 Cf. also Padgett and Zygis (2003) for discussion. 
(34)

a. s, cf. Wierzchowska (1980:64)

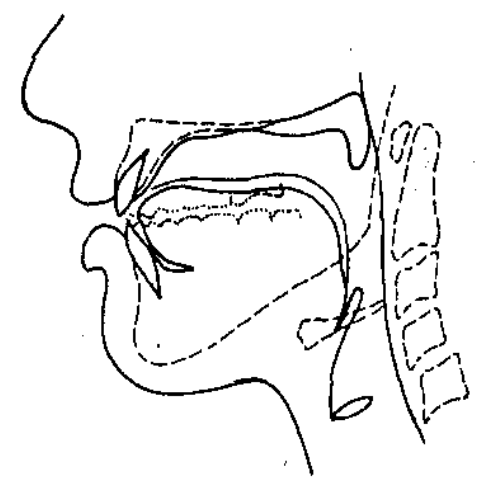

b. 6 , cf. Wierzchowska $(1980: 64,98)$

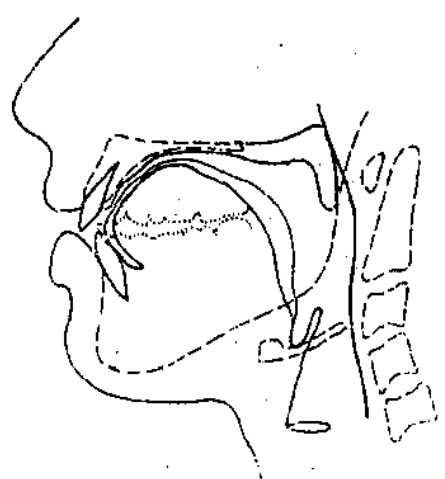

While there is no doubt about the retroflex nature of the sound in (34a), cf. Hall (1997), Halle \& Stevens (1997), Hume (1992), Hamann (2003), the description of 6 encounters difficulties. Hume (1992) observes that the alveolo-palatal sound shares similarities with the postalveolar $\int$ regarding the raising of the tongue blade and with palatal consonants due to the raising of the front of the tongue. She assumes, following Ladefoged \& Maddieson (1986), that alveolopalatals are to be characterized as palatalized postalveolars $\left(f^{j}\right)$. This view is also shared by Halle \& Stevens (1997) and Hall (1997b). The difference between Hume's and Halle \& Stevens' approach is that the former does not allow the existence of an underlying contrast between $\varphi$ and $\rho^{j}$, while the latter treats the segments as the same sounds on the surface: $\zeta$ and $z$ are to be interpreted as palatalized postalveolars, i.e., $\int^{j} 3^{j}$ (Stevens \& Halle 1997, Hall 1997b). Ladefoged \& Maddieson (1996:150) also interpret palatalized postalveolars as alveolo-palatals. In Hamann \& Rochoń (2002) we have provided perceptive evidence showing that $\int^{j} 3^{j}$ is not identical with $\varphi z$ and therefore shoud be treated as separate sounds.

As the pictures in (34) show, the difference between $s$ and 6 concerns not only the tongue shape but also the involvement of the active articulator. While in (34a) the tongue shape is rather flat with a slight velarization, in (34b) the tongue is 'domed'. Consequently, Polish $\$$ is articulated with the tip of tongue, while 6 with the tongue blade. The second difference concerns participation of the lips. In the case of s lips are rounded, while they are spread in the articulation of $\varphi$, cf. also Dogil (1990).

Let us now discuss the difference between 6 and $\int$. Recall the picture in (25) which shows the Bulgarian $\int$. Comparing $\int$ with $\varphi$ there is a clear similarity: both sounds are produced with the tongue blade. Moreover, in both cases the tongue body is raised and 'domed'. However, there are at least two important articulatory gestures that differ in the articulation of the sounds. The first one concerns participation of the lips. In the case of $\int$ the lips are rounded, whereas they are spread in the articulation of 6 . The second difference pertains to a channel created during the articulation. Puppel, Nawrocka-Fisiak \& Krassowska (1977) point out that in the articulation of 6 the air escapes through a very narrow channel made between the post-alveolar region of the palate and the middle of the tongue. In the case of $\int$ the channel is not so narrow and the constriction is more widely spread.

Let us proceed to the acoustics of the sibilants under consideration. In the following I present the results of acoustic measurements of sibilant fricatives presented in Slavic languages. The investigation includes sibilants attested in three representative languages, Bulgarian, Polish and Russian. The choice of the languages is motivated by the occurrence of different sibilant inventories, which I repeat in (35) for convenience. 
(35) Sibilant fricative systems

a) Bulgarian

b) Polish

$\begin{array}{llll}\text { alveolar } & & \text { postalveolar } \\ \mathrm{S} \quad \mathrm{Z} & \mathrm{s}^{\mathrm{j}} & \mathrm{z}^{\mathrm{j}} & \int \\ & \int\end{array}$

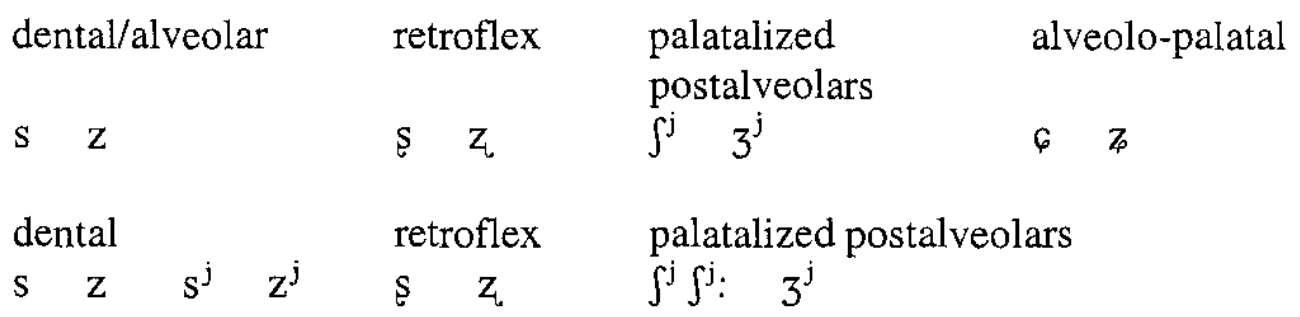

The acoustic measurements are limited to voiceless fricatives: $s, s^{j}$ and $\int$ in Bulgarian, $s, s, \int^{j}$ and $G$ in Polish, and $s, s^{j}, s$ and $\int^{j}$ in Russian. Note that the palatalized postalveolars have not been included in the phonemic inventory of Standard Polish before, cf. (1). As mentioned they are generally not perceived of as phonemes of Standard Polish, cf. e.g. Rubach (1984), Szpyra (1995). It has also to be pointed out that the pronunciation and perception of Polish $\left[{ }^{j}\right]$ significantly differs from that of Russian palatalized postalveolar [ $\left.\int^{j}\right]$ : while in the former case only the second part seems to be palatalized, i.e. influenced by $\mathrm{i} / \mathrm{j}$, in the latter case the whole fricative portion is palatalized and therefore similar to Polish [6]. This difference is also partially mirrored in the acoustic measurements presented below.

The experimental design is the same as in Zygis and Hamann (2003) where we presented results of two other native speakers of Polish. In this study four Bulgarian, four Polish $^{30}$ and four Russian native speakers (two males and two females of each language) participated at the experiment. None of the 12 speakers reported any history of speech or hearing difficulty. The recordings were made at $22.05 \mathrm{kHz}$ on DAT tape, most of them in a sound-proof laboratory and digitalized with the PRAAT program. A few recordings were made outside the lab by the help of high quality microphone and high quality cassette recorder. Acoustic analyses were also conducted with PRAAT.

As far as the experimental context is concerned, the sibilants under consideration were repeated ten times prevocalically in - a context. The - a context was motivated by the fact that $a$, in contrast to other vowels like $u$ or $i$, influences the fricative neither by rounding nor by palatalization as $u$ and $i$ do, cf. Mann \& Repp (1980), Johnson (1991), Mann and Soli (1991), Whalen (1981) for the role of the quality of the following vowel in listeners' identifications of fricatives.

The analyses of the acoustic data presented below focus on the measurements of the center of gravity (COG). COG is the first spectral moment of the spectral distribution ${ }^{31}$ and it is interpreted as a measure for how high the average frequencies in a spectrum are. In other words, it is spectral mean, cf. for more details Forrest et al. (1998), Jongman et al. (2000), Gordon et al. (2003).

The choice for measurements of COG is motivated by the fact that it reliably distinguishes between the spectral shapes of the fricatives, cf. Nittrouer et al. (1989) for the distinction between $\mathrm{s}$ and $\int$ in English. In terms of perception (and articulation) it provides

\footnotetext{
30 Cf. also Zygis and Hamann (2003) where we have provided COG measurements for sibilants of two other Polish native speakers.

31 Other three moments are variance (the second), skewness (the third) and kurtosis (the fourth), cf. Jongmann et al. (2000) for further details.
} 
more information than e.g. frequencies and/or amplitudes of single spectral peaks or durational properties. From the articulatory point of view, COG correlates with the size of the front cavity. With a more anterior constriction, the cavity is smaller and hence the COG value must be higher. On the other hand, if the constriction is located at further postanterior places, then the front cavity is larger and the spectral mean is lower. This means that there must be a difference between COG values of an dental/alveolar $s$ and a retroflex $s$ because the front cavity is considerably smaller in the first case. Such a difference is indeed visible in the results presented below. More importantly, measurements of COG provide important information for the acoustic 'distance' between the single sibilants and lead to at least preliminary conclusions with respect to the perception of the sounds. Many previous studies have argued or suggested that the most important information for the recognition of coronal sibilant fricatives is gained from their spectral properties rather than from the vowel context, cf. e.g. Hughes and Halle (1956), Evers et al. (1998) and references therein. The present study makes a similar assumption and investigates only the spectral properties of the fricatives under consideration. The results are shown in two parts for every speaker. In both parts, the COG is calculated for the whole duration excluding the first and the last $5 \%$ of the signal. In the first part, however, the fricative portion is treated as one signal to be investigated, i.e., only one COG value is calculated, while in the second part three COG values are calculated because the fricative portion is divided in three equal intervals. The latter strategy follows from the fact that some of the fricatives under consideration are palatalized which means that the second part and/or third part of the fricative might display different spectral properties than the first part. In order to visualize these changing properties of a palatalized segment, a separate treatment of its parts seems to be an appropriate strategy to follow.

In addition, it should be stressed that the statistical methods in classification of the results obtained is not provided here. There are reasons for presenting the measurements in the form of graphs. First, the graphs immediately show the COG values for every item under investigation and more importantly, they mirror an acoustic relation among all fricatives in a given inventory. Secondly, the individual differences between the speakers of the same language which are often reported to be especially drastic regarding fricatives, cf. Ladefoged and Maddieson (1996), are also reflected in a comprehensible manner.

Starting with the Polish inventory, four voiceless coronal fricatives $s \leq \int^{j}$ and 6 were analyzed in -a context. In (36) COG values obtained for the whole fricative portion of each sibilant are shown. Pictures (36a,b,c,d) correspond to the results obtained from the fricatives of four native speakers of Polish, i.e. AT (female), SK (female), DK (male), WW (male), respectively. The horizontal axis displays $\mathrm{COG}$ values in $\mathrm{kHz}$. On the vertical axis IPA symbols corresponding to the sounds under investigation are displayed.

(36) Polish

a. speaker AT

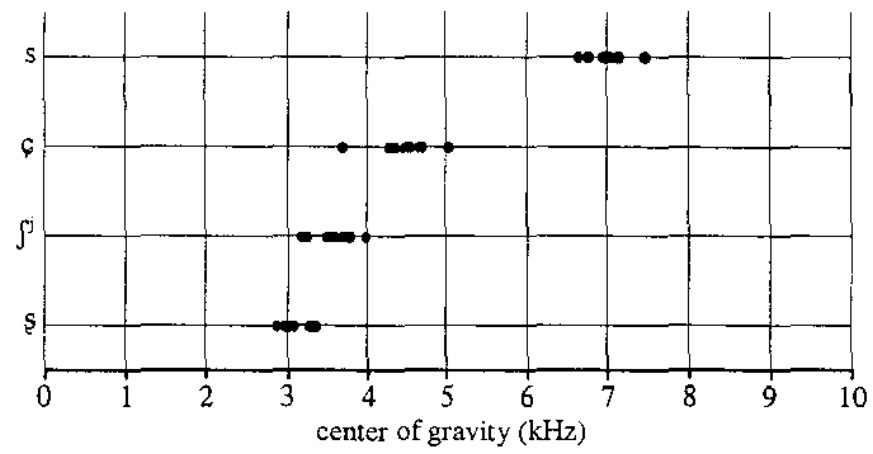


b. speaker SK

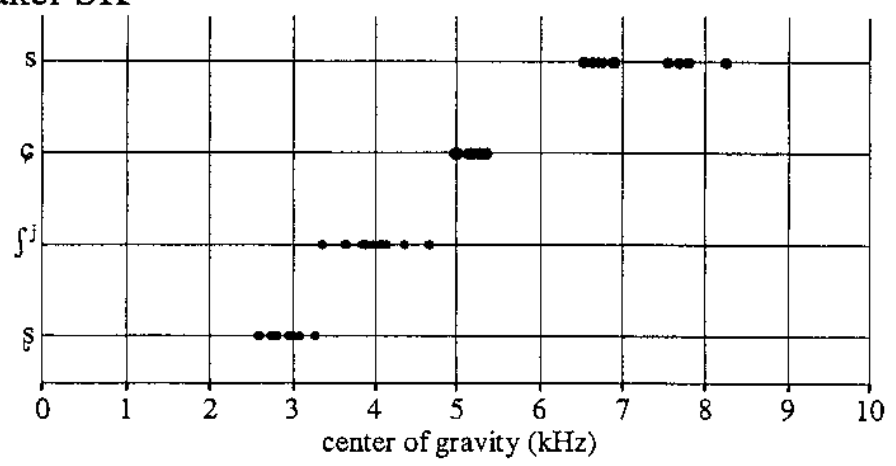

c. speaker DK

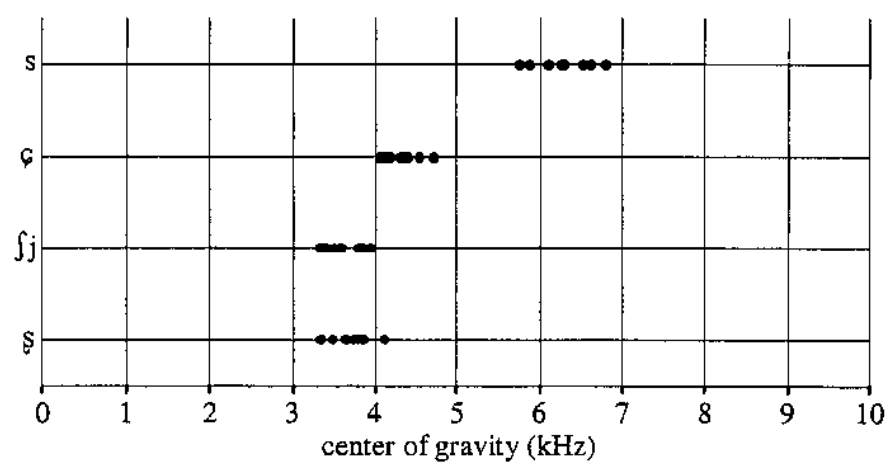

d. speaker WW

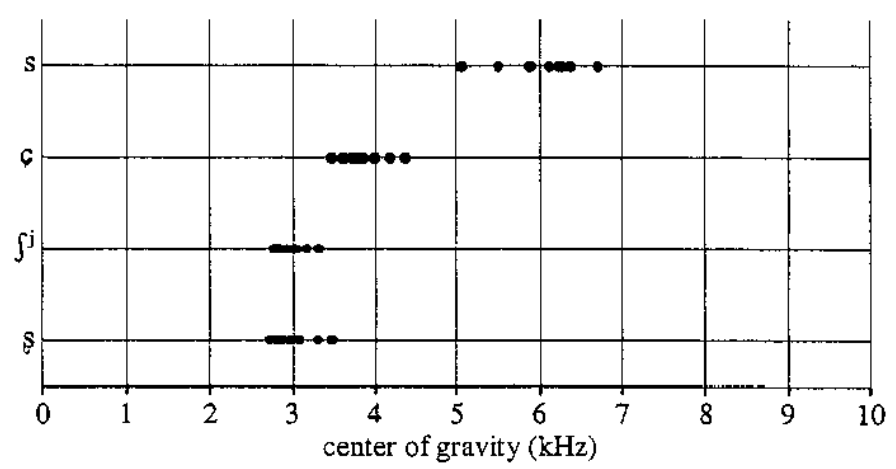

The results presented in (36) show a clear correlation between constriction frontness and center of gravity. First, s displays the highest gravity centers from all sibilants investigated. This is attributed to the smallest cavity in front of its constriction, cf. Stevens (1998) and also Fant (1960) for the relationship between spectral properties of the sibilants and constriction location. ${ }^{32}$ The next highest values are obtained by the alveolo-palatal 6 in all four cases (36a,b,c,d) which is also in accordance with the larger size of its front cavity compared to s. The lowest $\mathrm{COG}$ values in the range from 2,5 to $3,5 \mathrm{kHz}$ are displayed in the retroflex by the first (AT) the second (SK), and the fourth speaker (WW). This is in line with the expectations: the retroflex has the largest cavity from all the coronal sibilants and the smallest COG values, respectively. Additionally, it has been reported that this sound is accompanied by some rounding, cf. e.g. Wierzchowska (1971), Dogil (1990), which enlarges the front cavity and

32 Stevens (1989) stresses that the back cavity, i.e., behind the constriction hardly contributes to the changes in the spectral properties. 
leads to decreasing $\mathrm{COG}$ values. COG results obtained by speaker $\mathrm{DK}$ are slightly higher (from approximately 3,5 to $4,1 \mathrm{kHz}$ ) and therefore closer to $\int$. This individual diferrence can be attributed to the fact that $\int$ with its higher COG values is not attested in Polish and therefore the retroflex $s$ is sporadically produced with higher frequencies, almost as $\int$. Whereas there is almost no overlap between $\epsilon$ and $s$ by all four speakers, a considerable COG overlap between $\int^{j}$ and $S$ is visible in three cases apart from speaker SK. A helpful insight into the realization of this sound should be provided by the measurement where the fricative was inspected at three intervals, cf. results discussed below.

In the following COG values for three intervals for all four sibilants are presented. The graphs in $(37 \mathrm{a}, \mathrm{b}, \mathrm{c}, \mathrm{d})$ show the results obtained by speakers AT, SK, DK and WW, respectively. Different lines shown in the graphs correspond to different sibilants. The solide line (at the top) stands for $s$, the dashed one for 6 , the dotted one for $\int^{j}$ and the solid one (at the bottom) for the retroflex $\mathrm{s}$. The vertical axis displays COG values in $\mathrm{Hz}$ and the horizontal axis shows time in ms.

(37) Polish sibilants

a. speaker AT

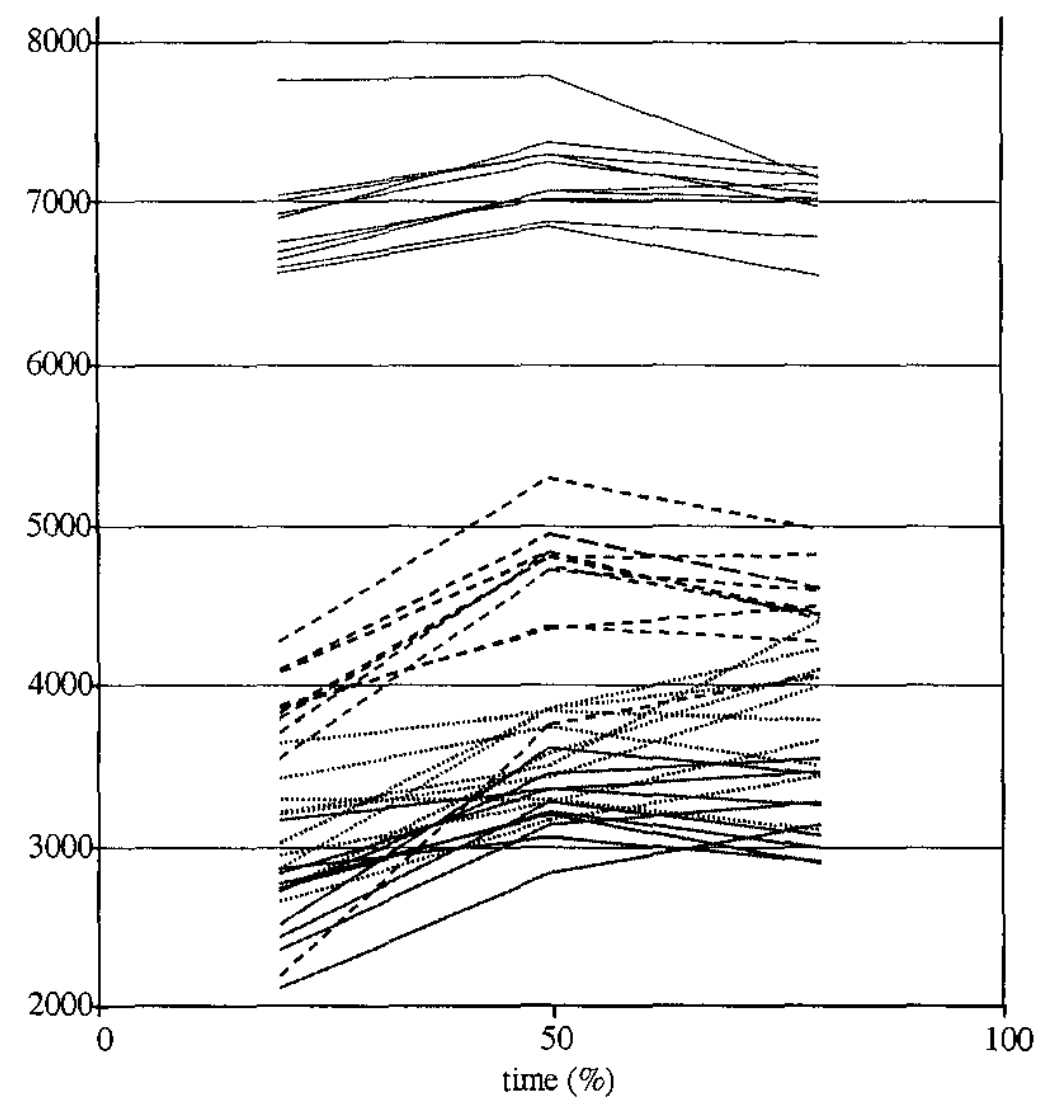


b. speaker SK

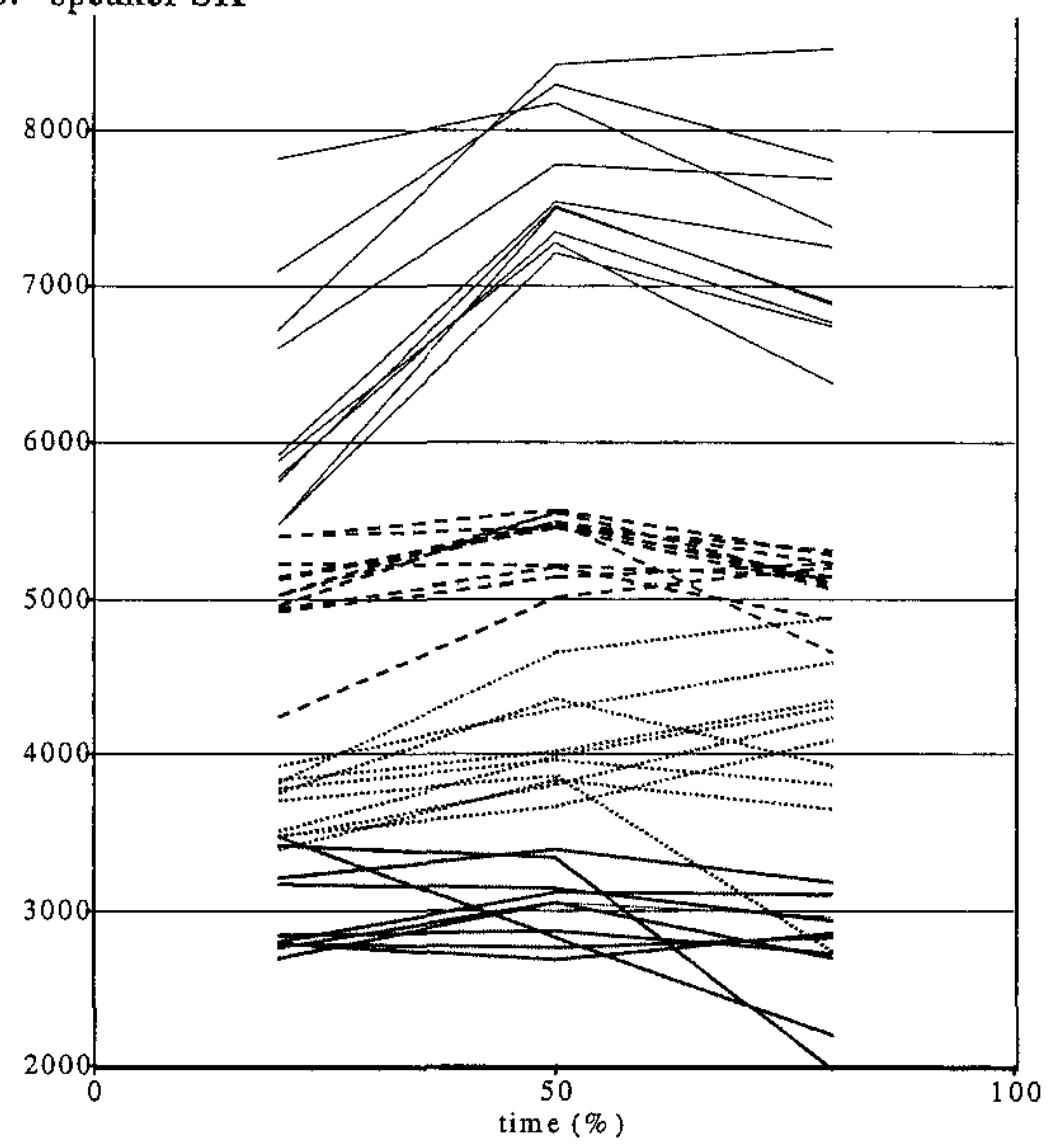

c. speaker DK (male)

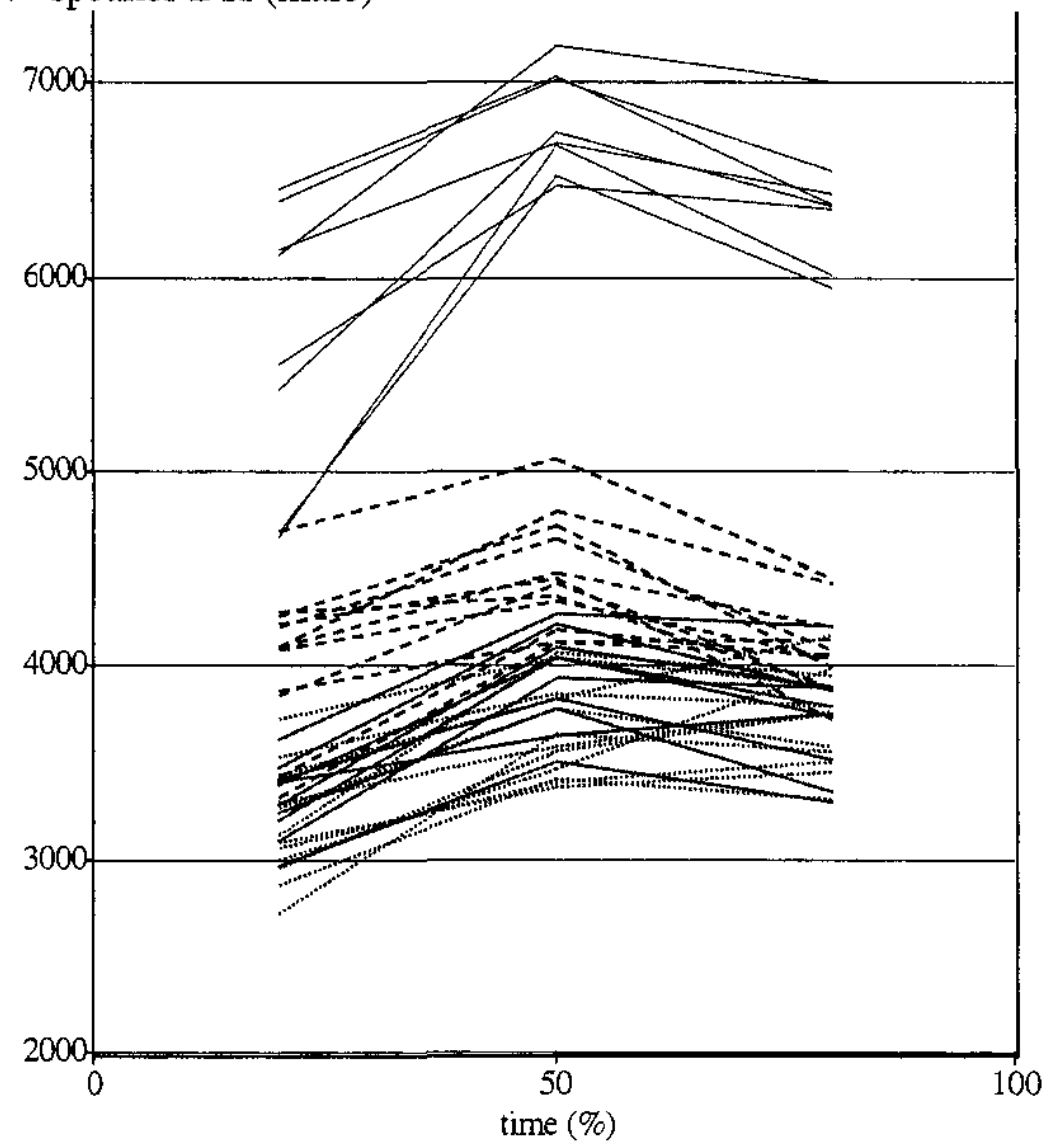


d. speaker WW

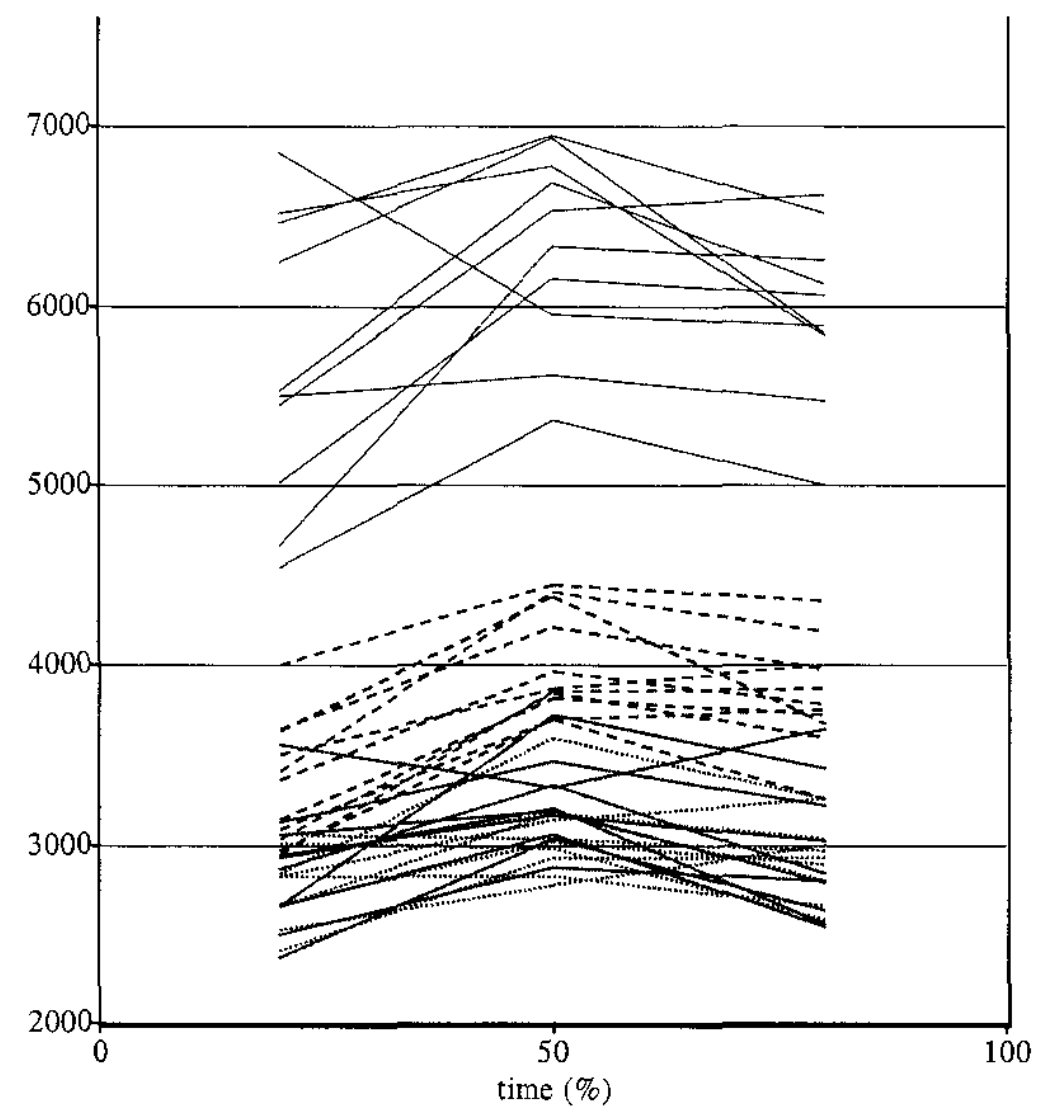

Again, all speakers display the same rank ordering of the three fricatives $s, 6$, and $s$. As far as $\int^{j}$ is concerned a partial, a complete or no overlap with s can be stated. The first speaker AT shows a very little overlap between $s$ and $\int^{j}$ in the second and especially third interval, while the second speaker SK displays no overlap between the sounds. However, there is almost no difference visible in the time-varying COG values obtained by the third and the fourth speaker. This shows that the second part of a palatalized fricative can differ from the first but it does not have to. It also means that the fricative can be either palatalized through the whole signal or the cues for palatalization can be placed in the following vowel, which has not been taken into consideration in these measurements. Since $\int^{\mathrm{j}}$ and $\mathrm{s}$ are almost indistinguishable in $(37 \mathrm{c}, \mathrm{d})$ the second explanation seems to be more adequate.

In the following, results of COG measurements of Bulgarian fricatives will be shown. Sibilants $s, s^{j}$ and $\int$ adjacent to the vowel $-a$, i.e. $s a, s^{j} a$ and $\int a$ were repeated ten times by four native speakers of Standard Bulgarian. In $(38 a, b, c, d)$ the results of measurements of COG values for the fricative signal are presented. The order of the graphs corresponds to the results obtained by two female (LX, DT) and two male (ZZ, HV) native speakers of Bulgarian. 
(38) Bulgarian sibilants

a. speaker LX

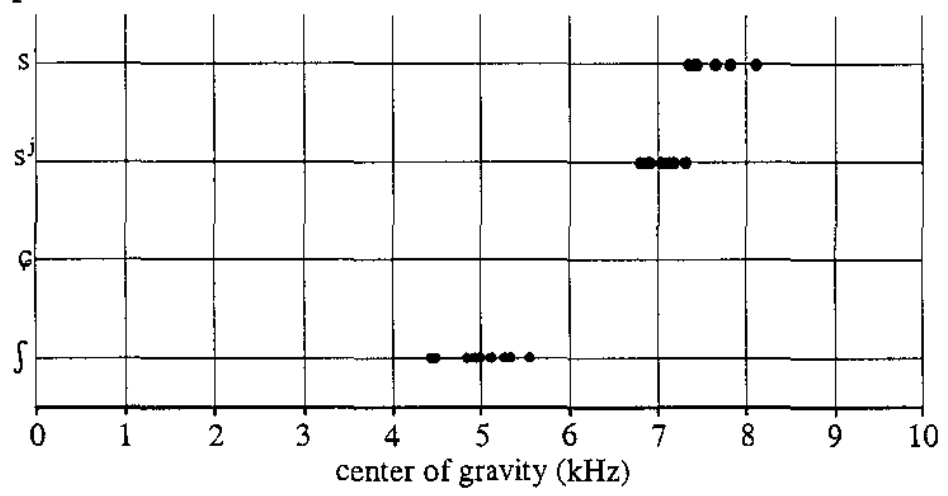

b. speaker DT

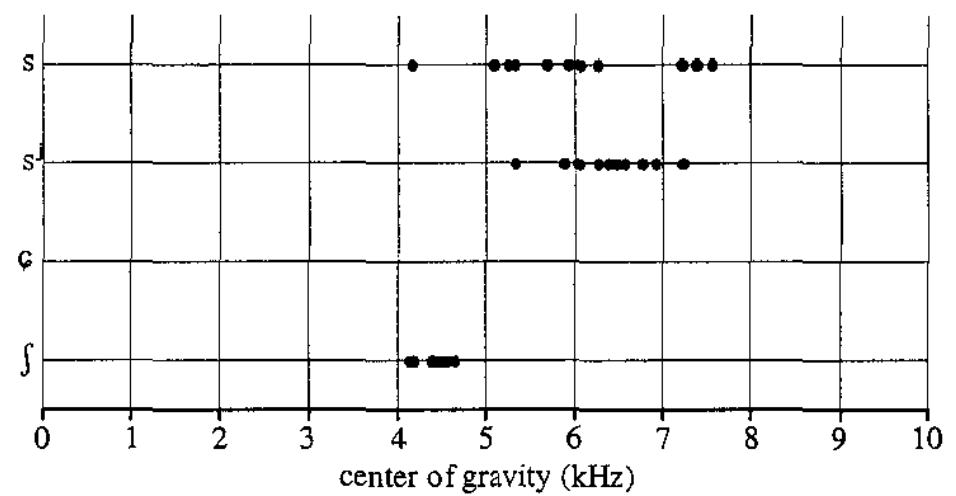

c. speaker ZZ

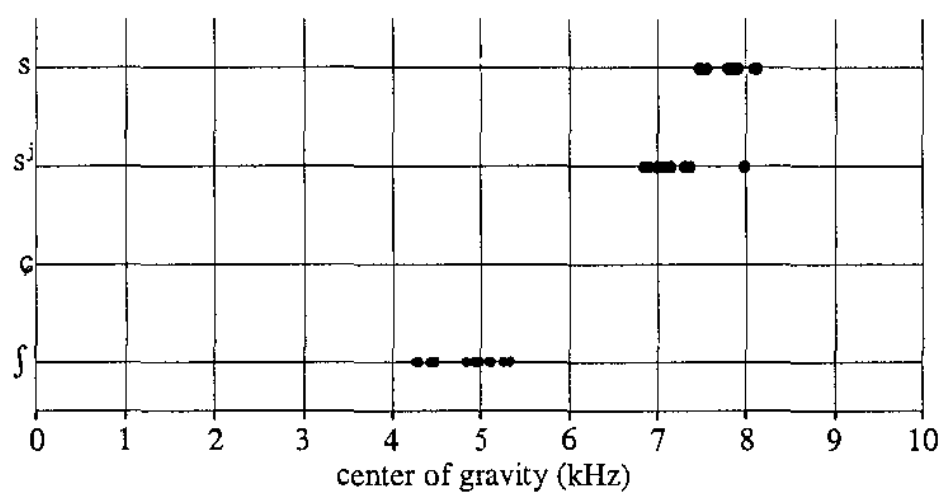

d. speaker $\mathrm{HV}$

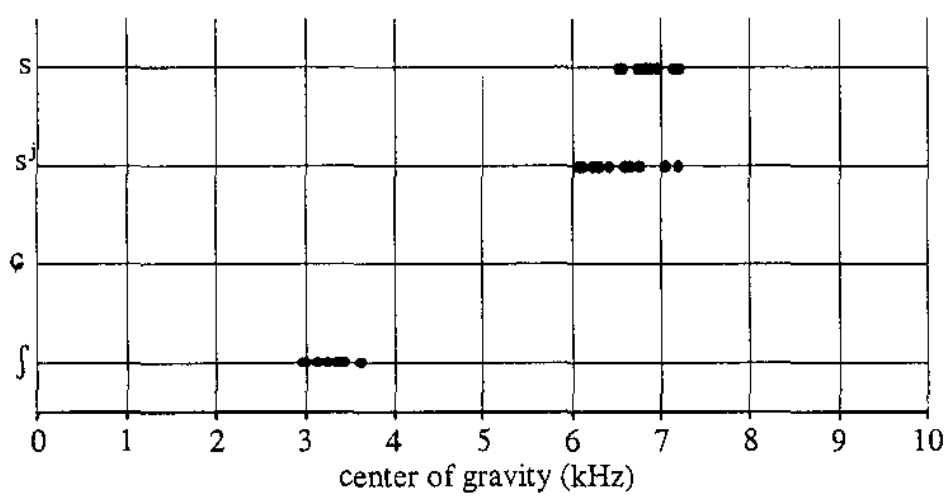


The results show a difference between Polish $S$ and Bulgarian $\int$. The latter one displays higher COG values, i.e. approximately between 4 and $5 \mathrm{kHz}$, (excluding the fourth speaker) than the Polish retroflex. The results confirm the retroflex status of the Polish $\mathbf{s}$ because retroflexion is associated with the lowering of frequency noise concentration in comparison to posterior sounds, a difference which follows from the results presented thus far. Furthermore, the graphs in (38) show an evident overlap between $s$ and its palatalized counterpart $s^{j}$ in all four cases. Whether this overlap concerns only a part of fricative portions will be shown by the next graphs in (39). But this finding hints at strong perceptual similarity between $s$ and $s^{j}$, which suggest that their coocurrence is not optimal or preferable from a perceptual point of view. Another striking point is that COG values for both $s$ and $s^{j}$ are widely spread, which shows not only an interspeaker variation, as reported in several studies on (sibilant) fricatives (cf. Gordon et al. (2000), Hughes and Halle (1956)) but also an intraspeaker variation.

Continuing with Bulgarian sibilants, the graphs in (39) show COG values for three intervals for all three sibilants i.e. $\mathrm{s}, \mathrm{s}^{\mathrm{j}}, \mathrm{f}^{\mathrm{j}}$. Again, each graph mirrors results obtained by one speaker. The lines correspond to the following sibilants: the solide line (at the top) stands for $\mathrm{s}$, the dashed one for $\mathrm{s}^{\mathrm{j}}$, and the solide one (at the bottom) for the postalveolar $\int$.

(39) Bulgarian sibilants

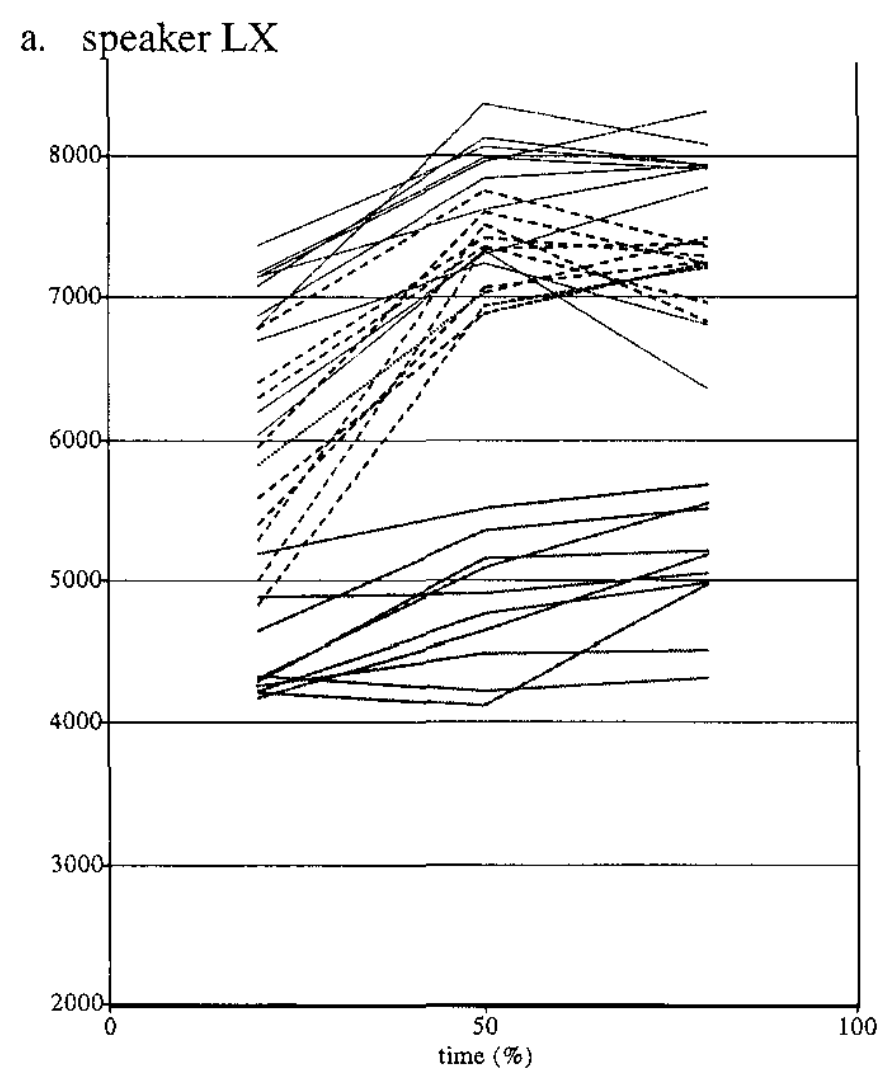


b. speaker DT

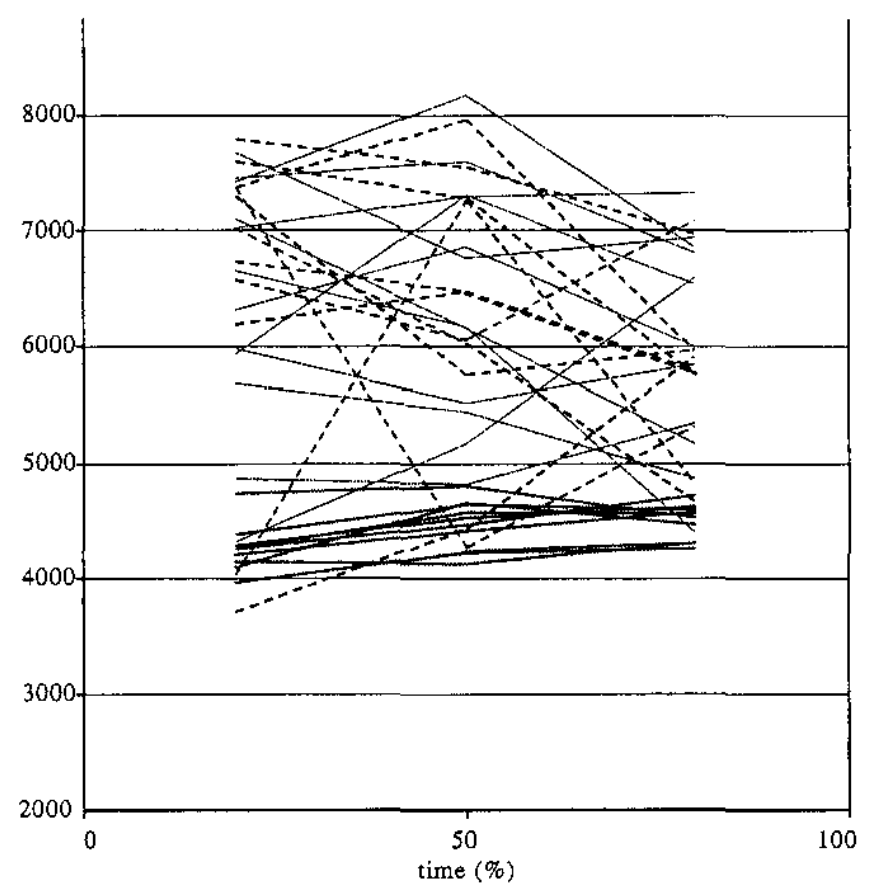

c. speaker ZZ

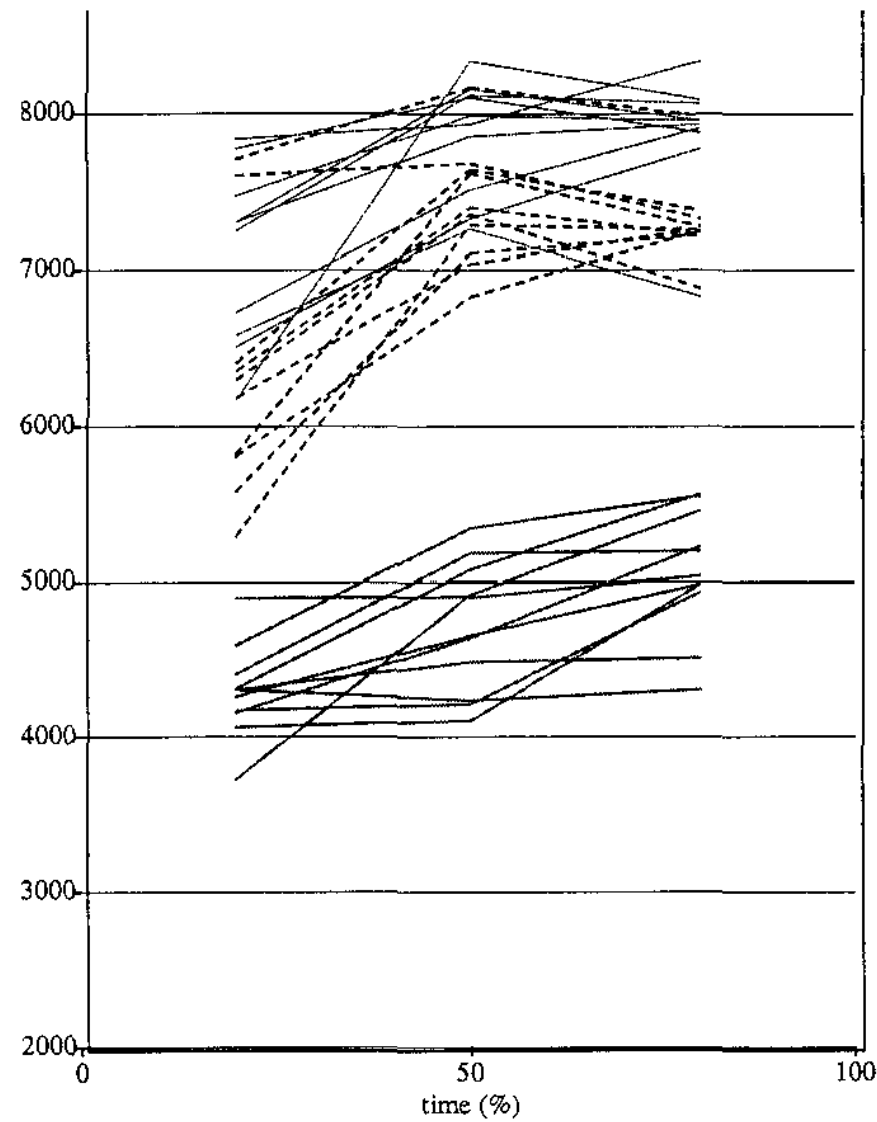




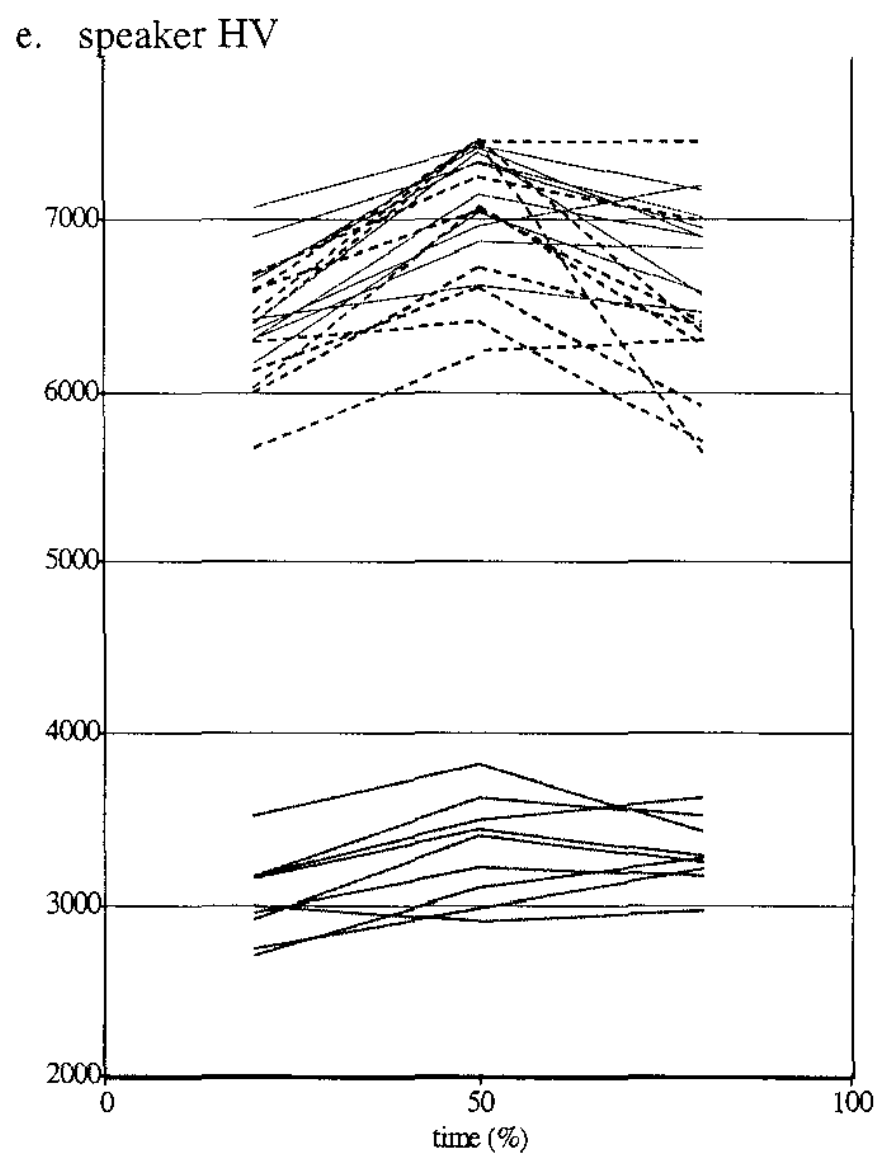

Considering the graphs in (39) it is evident again that the COG values of $\int$ are generally higher than those of the corresponding Polish sound $s$. As far as $s$ and $s^{j}$ are concerned, the COG values overlap in all four cases, although a certain preference for slight lower values of $s^{j}$ than of $s$ is visible. In addition, speakers $L X$ and $Z Z$ show lower values of $s^{j}$ and $s$ in the initial part of fricative noise. The results obtained for the speaker DT are a striking example of the intraspeaker fricative variation..$^{33}$

The last language to be discussed is Russian. Its four sibilants, $s, s^{j}, \int^{j}, s$, were analyzed in the same way as Polish and Bulgarian fricatives. Again, four native speakers of Standard Russian, two females (speakers LG, FX) and two males (speakers VB, MX) participated at the experiment. The results are shown in (40).

(40) Russian sibilants

a. speaker LG

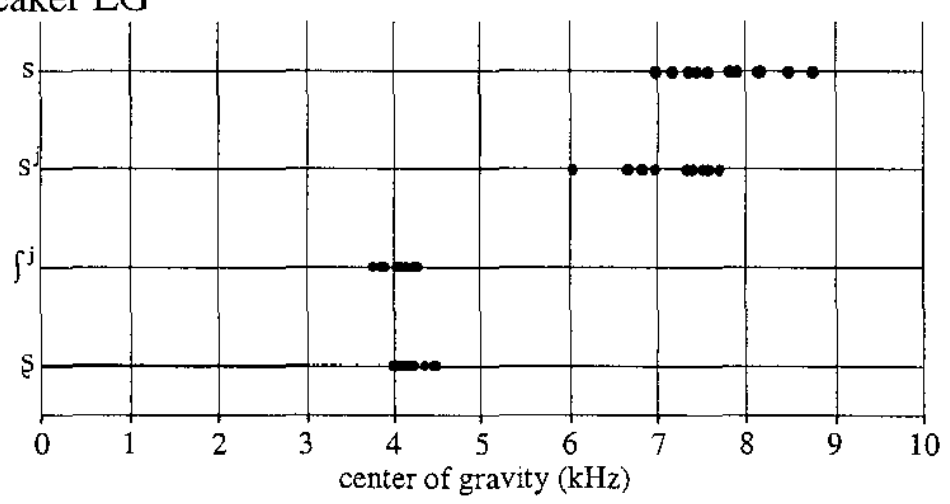

33 With the speaker DT I also conducted an experiment with the sibilants in other vowel contexts, i.e. -i and $u$. In both cases the informant shows a great variation in COG values for $s^{j}$ and $s$. 
b. speaker FX

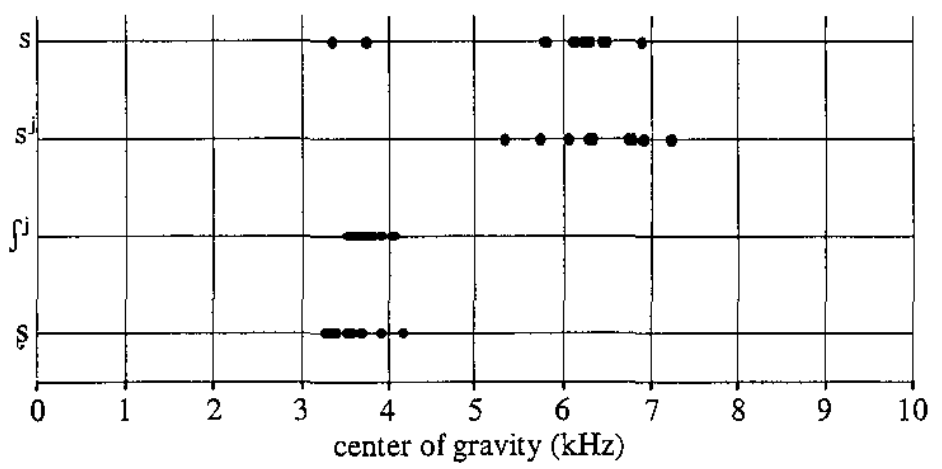

c. speaker VB

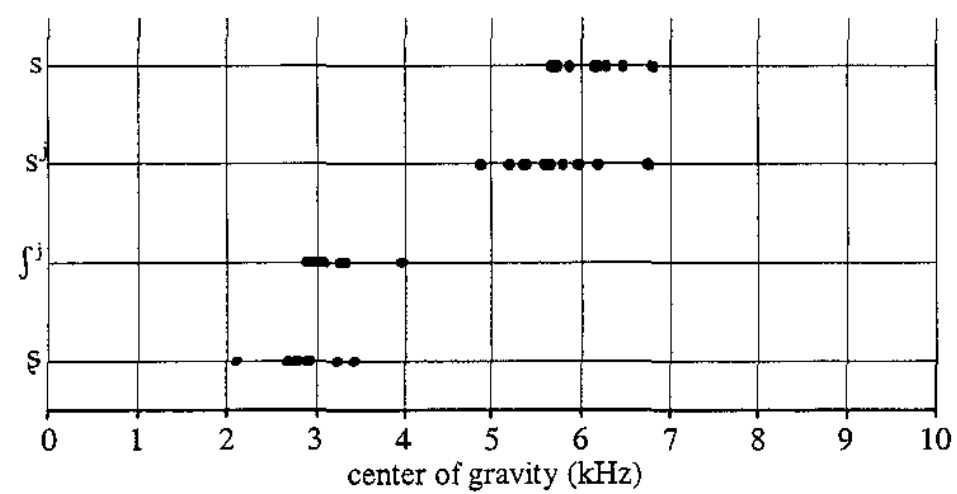

d. speaker MX

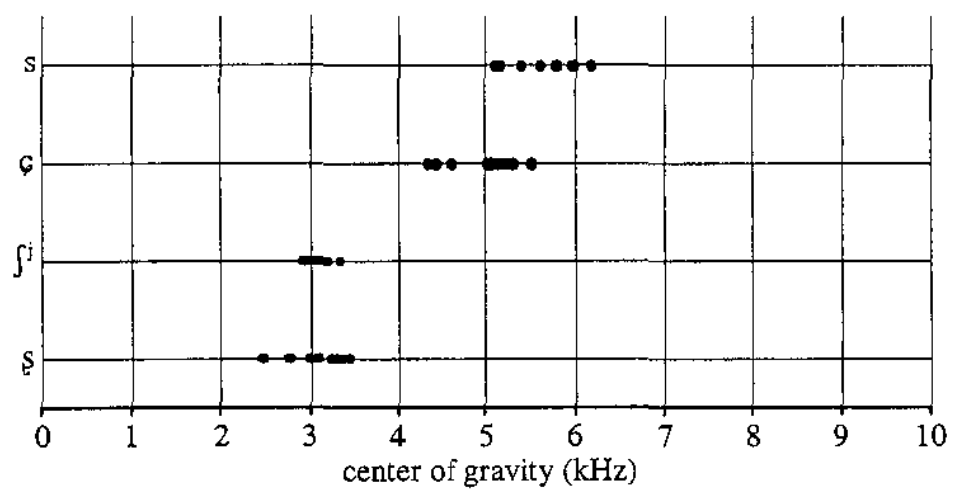

As in the case of Bulgarian, there is a considerable overlap between $s$ and its palatalized counterpart $s^{j}$. Interestingly, the COG values of $s$ and $\int^{j}$ totally overlap, even more than in Polish where the $\int^{j}$ appears allophonically. But as far as $s$ is concerned, the COG values between 2,5 and 3,5 (maximally $4 \mathrm{kHz}$ for speaker FX) suggest that it is retroflex. Again, there is one exception concerning this point: Values obtained by speaker LG go up to more than $4,5 \mathrm{kHz}$. This phenomenon can be attributed to the fact that the speaker LG could be influenced by German $\int$ because she has spent over ten years in Germany and speaks fluent German. 
A closer inspection of the data also suggests a difference between the realization of retroflexes by females and males, because the divergence in COG values of these sibilants splits the results in male (COGs lower) and female ones (COGs higher). This point requires, however, further investigation, cf. Gordon et al. (2002) for the differences between pronunciation of female and male informants.

In (41) the COG values for the intervals of the Russian sibilants are displayed. Each graph mirrors results obtained by one speaker. The lines correspond to the following sibilants: the solide line (at the top) stands for $s$, the dashed one for $s^{j}$, the dotted one for $\int^{j}$, the solide line (at the bottom) for $s$.

(41) Russian sibilants

a. speaker $\mathrm{LG}$

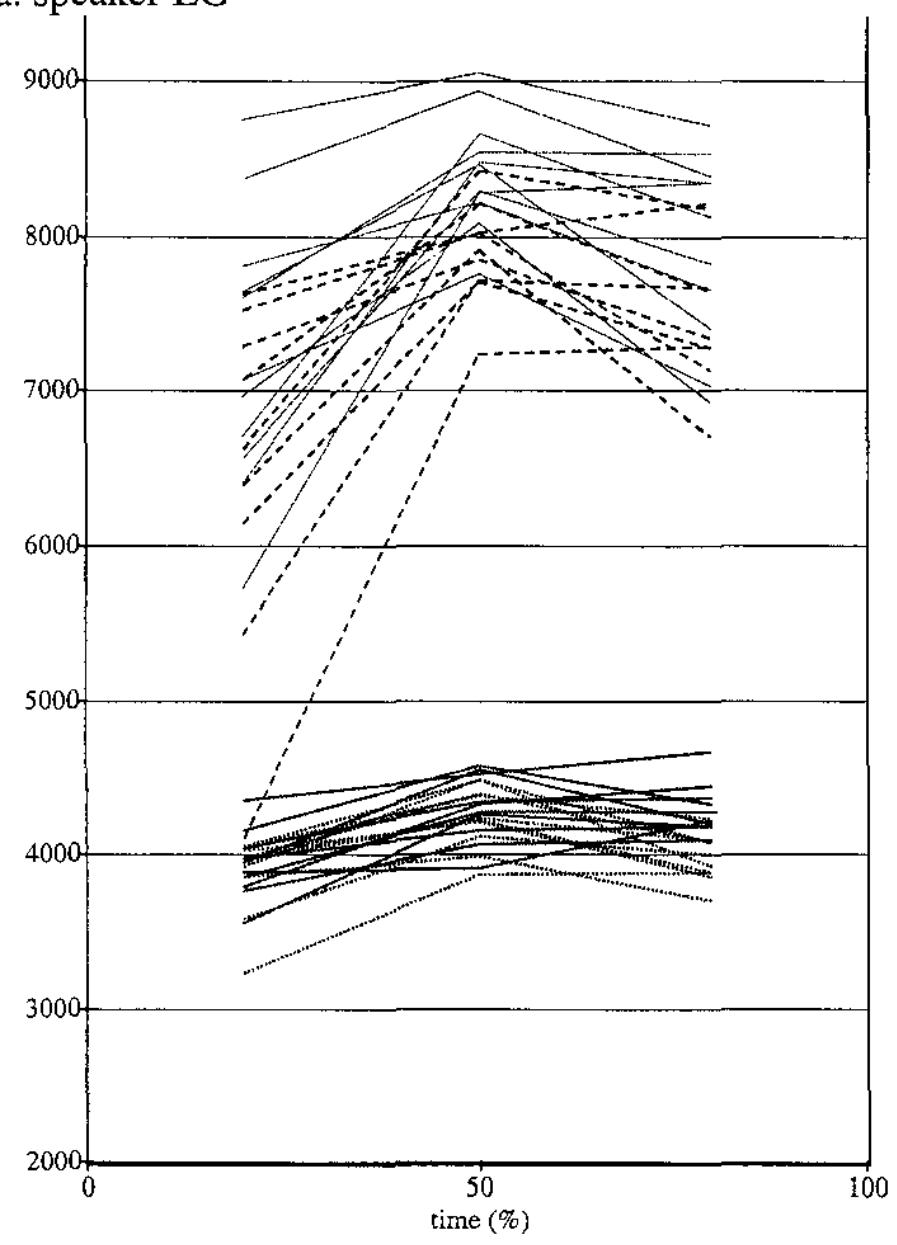


b. speaker FX

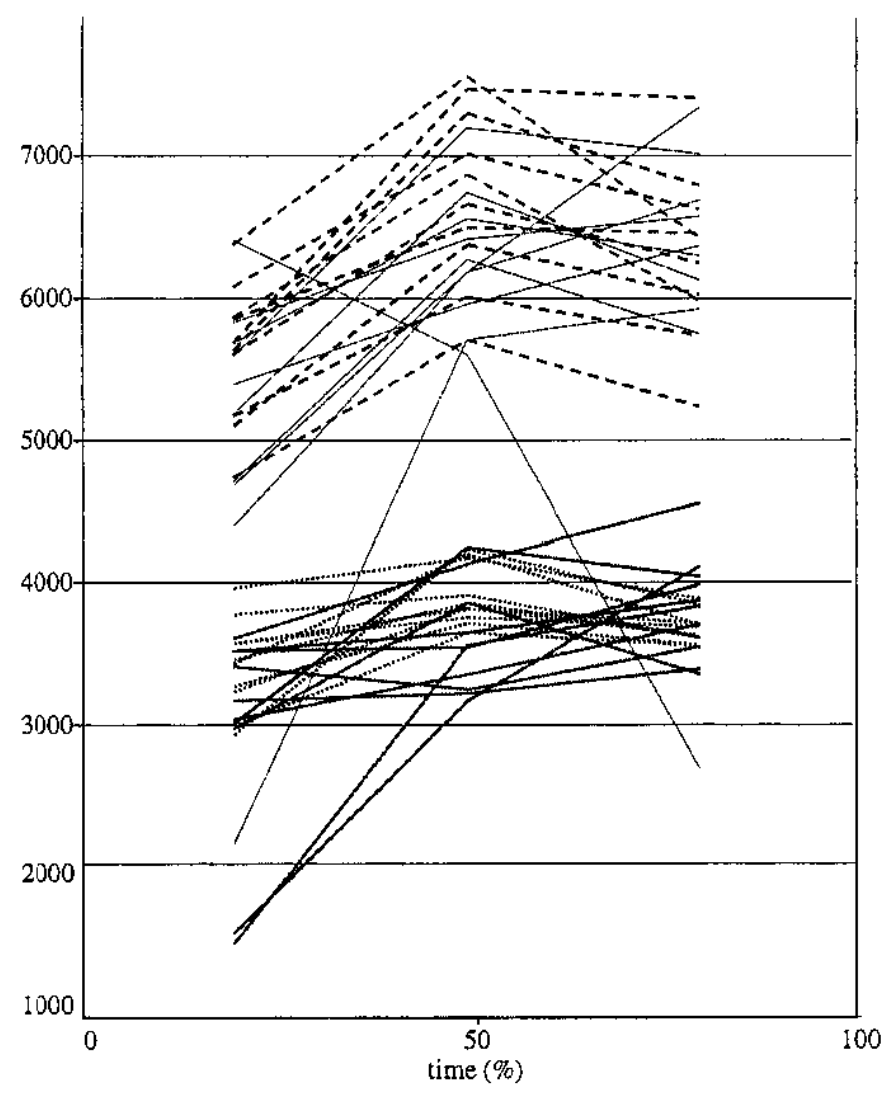

c. speaker VB

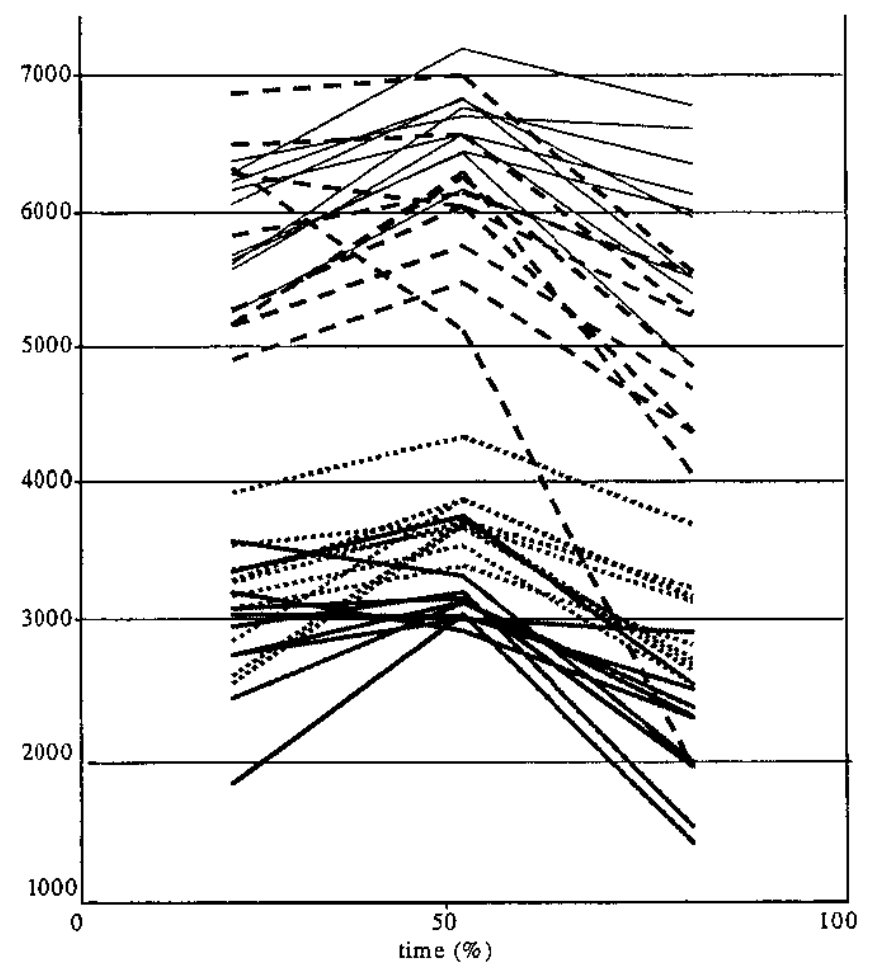


d. speaker MX

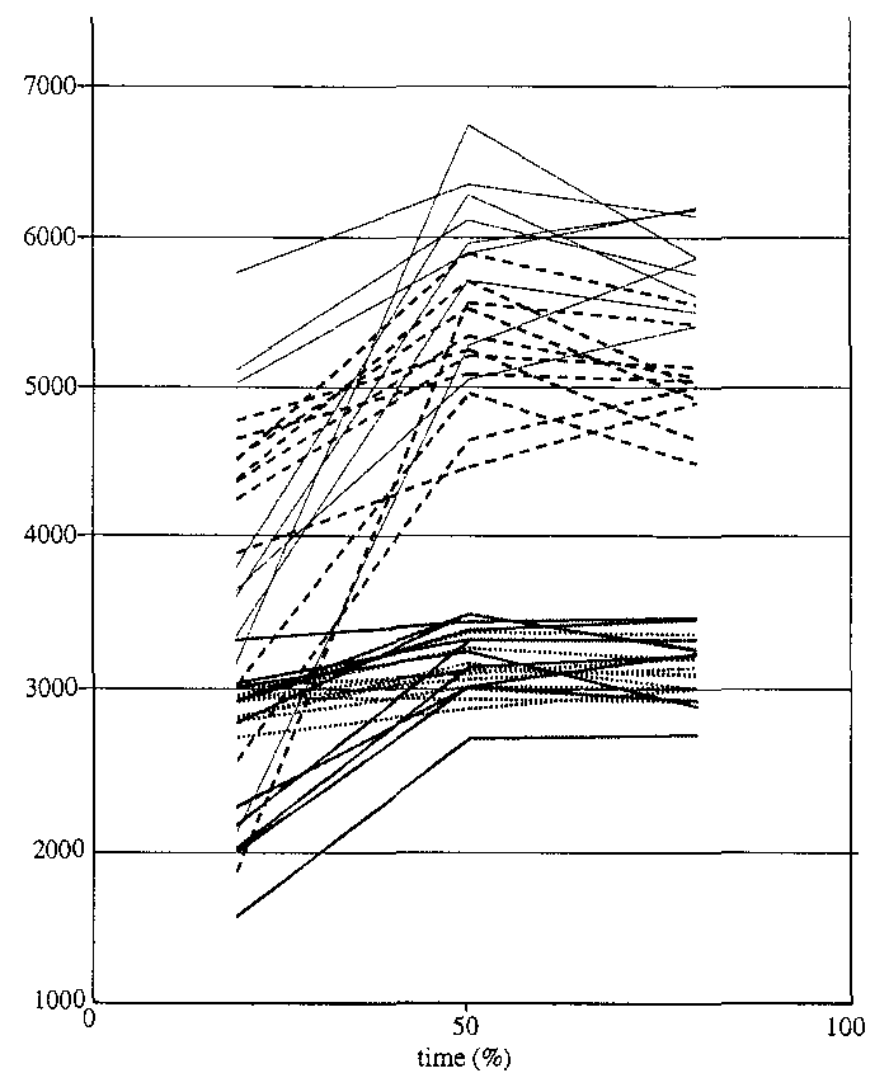

What the results in (41) show is a split between $\mathrm{s} / \mathrm{s}^{\mathrm{j}}$ and $\int^{\mathrm{j}} / \mathrm{s}$. However, as in the case of Polish there is no clear distinction between $\int^{j}$ and $s$, As far as $s$ and $s^{j}$ are concerned, the situation is similar to that found in Bulgarian, the COG values for $\mathrm{s}^{j}$ are slightly lower than these for $\mathrm{s}$. Unfortunately, the COG values pertaining to three different parts of the fricative do not show a great difference between $s$ and $\int^{j}$, similary to Polish $s$ and $\int^{j}$. This shows that both sounds are acoustically very close to each other and other acoustic measurements have to be done in order to distinguish the segments.

Apart from conclusions presented above, the experimental results also provide answers to questions presented in (33), and repeated in (42).

a. Why are the systems $/ \mathrm{s} \quad \mathrm{g} /$ and $/ \mathrm{s} \int^{j} \mathrm{~s} /$ not optimal?

b. Why is the system /s $6 \mathrm{~s} /$ preferred to $/ \mathrm{s} 6 \mathrm{~J} /$ and $/ \mathrm{s} \int^{\mathrm{j}} \mathrm{s} /$ ?

c. Why does $\int / \int^{\mathrm{j}}$ change to $\mathrm{s}$ in some inventories, while in others remains intact?

d. Why is it that $\int$ changes and not 6 ?

e. Why do palatalized dentals/alveolars change to alveolo-palatals?

f. Why do alveolo-palatals and not palatalized dentals/alveolars usually trigger the change from $\int$ to $s$ in sibilant systems?

First, the experimental results show that the systems $/ \mathrm{s} \quad 6 \int /$ and $/ \mathrm{s} \int^{\mathrm{j}} \mathrm{s} /$ are not optimal because the COG values of $\int$ and 6 (cf. Bulgarian $\int$ with Polish 6 ) as well as those of $s$ and $\int^{j}$ (cf. Polish $s$ and $\int^{j}$ or Russian $s$ and $\int^{j}$ ) often considerably overlap and therefore are not able to maintain an optimal perceptual contrast. Furthermore, the COG measurements also lend support to the fact that the system /s $\&$ s/ is preferred to $/ \mathrm{s} \in \int /$ and $/ \mathrm{s} \int^{j} \mathrm{~s} /$ by showing that the lower COG values of ss create a greater distance to 6 than the COGs of $\int$ to 6 (and the 
COGs of $\int^{j}$ to $s$ ) do. In both cases $\varphi$ and $\int$ as well as $\int^{j} s$ are closer to each other than $\varphi$ to $s$ is. It also becomes clear why $\int / \int^{j}$ changes to $s$ in some inventories, while in others remains intact, cf. question (42c). Considering the fact that $\int$ prefers not to change if it cooccurs with $s$ in a two-phoneme inventory, as e.g. in Czech, and it changes to s in three- and more sibilant systems, as in Polish or Russian, it can be concluded that the lowest COG values of $s$ are needed to make the postalveolar sibilant more distant to $\zeta$ or $\int^{j}$. The results also answer the question (42d). It is namely $\int$ that changes and not 6 because the change of $\zeta$ would involve either the rising of COG values towards $s / \mathrm{s}^{j}$ or the lowering of COG values towards $\int / \mathrm{J}^{\mathrm{j}} / \mathrm{s}$ causing in both cases the reduction of the perceptual distance. When $\int$ changes to $s$ the acoustic space and therefore the perceptual span are enlarged. In addition, the results clearly illustrate that palatalized dentals/alveolars $\left(\mathrm{s}^{\mathrm{j}}, \mathrm{s}^{\mathrm{j}}\right)$ change to alveolo-palatals because they overlap with dentals/alveolars (s, s) in terms of COG values. Finally, a convincing explanation is provided as to why alveolo-palatals and not palatalized dentals/alveolars usually trigger the change $\varphi \rightarrow \mathrm{s}$ in sibilant systems, cf. (42f). This results from the fact that the acoustic COG distance from $\mathrm{s}^{\mathrm{j}} / \mathrm{s}^{\mathrm{j}}$ to $\int$ is considerably greater that that from $\varphi$ to $\int$.

To summarize, it has been shown that some phonological processes and facts concerning sibilants are explained by appealing to phonetics, especially acoustics.

\section{Conclusions: marked vs. unmarked sibilant systems}

The present investigation has shown that acoustics/perception play an important role in the determination of sibilant systems. The improvement of perceptual contrast essentially contributes to creating new sibilant inventories by (i) changing the place of articulation of the existing phonemes (ii) merging sibilants that are perceptually very close or (iii) deleting them.

It has also been shown that the symbol š, traditionally used in Slavic linguistics, corresponds to two sounds in the IPA system: it stands for a postalveolar sibilant $(\delta)$ in some Slavic languages, as e.g. Bulagarian, Czech, Slovak, some Serbian and Croatian dialects, while in others like Polish, Russian, Lower Sorbian it functions as an retroflex (s). This discrepancy is motivated by the fact that $\int$ is not optimal in terms of maintaining sufficient perceptual contrast to other sibilants such as $\mathrm{s}$ and $\mathrm{c}$. If $\int$ occurs together with $\mathrm{s}$ (and $\mathrm{s}^{\mathrm{j}}$ ) there is a considerable perceptual distance between them but if it occurs with $\varphi$ in an inventory, the distance is much smaller. Therefore, the strategy most languages follow is the change from a postalveolar to a retroflex sibilant.

Taking into consideration the experimental results and two facts from the development of sibilants, i.e. $\mathrm{s}^{j} \rightarrow \mathrm{G}$ and $\int \rightarrow \mathrm{S}^{34}$ I propose the following three-step mechanism mirroring Slavic facts and leading to an perceptually optimal system.

1. $s$ and $s^{j}$ are perceptually not optimal, therefore $s^{j} \rightarrow G$,

2. $\quad G$ and $\int^{j}(\delta)$ are perceptually not optimal, therefore $\delta \rightarrow \S$

3. the system $s, 6$, s is perceptually optimal and therefore stable

The mechanism in (43) shows that every step leads to the perceptual improvement. In terms of changing the COG values it illustrates a domino effect: lowering of COGs of one sibilant causes COGs lowering of another. As a final result there is more perceptual space between the

34 In Padgett and Zygis (2003) we discuss the evolution of Polish and Russian sibilants in detail offering an analysis in the framework of Dispersion Theory. 
existing sibilants. Hence, it also becomes clear why $\int$ and not 6 changes: the latter is a trigger of the change of the former, cf. steps in (43). If 6 increased its COG values, it would be closer to $s$ and if it lowered them, it would most probably be too close to $\int$. This and other phenomena, cf. questions in (42), find its explanation by appealing to acoustics.

It has also been observed that the languages despense with complex sibilant contrasts by deleting or merging segments: a three-way contrast is reduced to a two-way one by merging the two postalveolar fricatives $\int$ and 6 into a single sound (Croatian, Serbian) or by deleting either the postalveolar or the alveolo-palatal sibilant (Polish dialects).

\section{Acknowledgments}

I am greatful to the audience at the FDSL-4 in Potsdam for the discussion on the oral version of the paper. A written, considerbly extended, version benefitted from T. Alan Hall's and Silke Hamann's helpful comments. I would also like to thank Silke Hamann and Paul Boersma for their PRAAT scripts which were used in providing COG graphs. I am also greatful to Hristo Velkov for helping me to find informants and to do recordings with them.

\section{References}

Akishina, A.A. \& S.A. Baranovskaja (1980): Russkaja fonetika. Moscow: Izdatel'stvo Russkij Jazyk.

Biedrzycki (1974): Abriß der polnischen Phonetik. Warszawa: Wiedza Powszechna.

Boersma, P. (1998): Functional Phonology. Den Haag: Holland Academic Press.

Bolla, K. (1981): A Conspectus of Russian Speech Sounds. Budapest: Akademiai Kiado. Bray, de R.G.A. (1951): Guide to the Slavonic Languages. London: J.M. Dent \& Sons Ltd.

Broch, O. (1911): Slavische Phonetik. Heildelberg: Carl Winter's Universitätsbuchhandlung.

Browne, W. (1993): Serbo-Croat. In B. Combrie \& G. G. Corbett (eds.): The Slavonic Languages, 306-387. London: Routledge.

Carlton, T.R. (1991): Introduction to the Phonological History of the Slavic Languages. Slavica Publishers: Columbus, Ohio.

Combrie, B. \& Corbett, G.G. (eds.) (1993): The Slavonic Languages. London: Routledge.

Dejna, K. (1994): Atlas polskich innowacji dialektalnych. Warszawa, Łódź: Państwowe Wydawnictwo Naukowe.

Dłuska, M. (1983): Fonetyka polska. Artykulacje glosek polskich. Kraków: Państwowe Wydawnictwo Naukowe.

Dogil, G. (1990): Hissing and Hushing Fricatives: A Comment on Non-anterior Spirants in Polish. Unpublished ms. Universität Bielefeld.

Dukiewicz, L \& R. Piela (1962): Wyrazistość i rozróżnialność głosek w języku polskim w zależności od górnej granicy częstotliwości. Przeglad Komunikacyjny 7, 213-217.

Fant, G. (1960): Acoustic Theory of Speech Production. The Hague: Mouton.

Flemming, E.S. (1995, 2002): Auditory Representations in Phonology. New York \& London: Routledge.

Gordon, M., Barthmaier, P. and K. Sands (2002): A Cross-linguistic Acoustic Study of Voiceless Frictives. Journal of the International Phonetic Associtation 32, 141-171.

Gussmann, E. (1980): Studies in Abstract Phonology. Cambridge, Mass: MIT Press.

Hall, T. A. (1997a): The Historical Development of Retroflex Consonants in Indo-Aryan. Lingua 101, 203-221.

Hall, T. A. (1997b): The Phonology of Coronals. Amsterdam: Benjamins.

Hall, T.A. (2000): Typological generalizations concerning secondary palatalization. Lingua 110,1-25.

Halle, M. \& G. N. Clements (1983): Problem Book in Phonology. Cambridge, Mass.: MIT Press.

Halle, M. \& K. N. Stevens (1997): The Postalveolar Fricatives of Polish. In S. Kiritani, H. Hirose \& H. Fujisaki (eds.): Speech Production and Language, 177-192. Berlin, New York: Mouton de Gruyter. 
Hamann, S. (2002a): Postalveolar Fricatives in Slavic Languages as Retroflexes. In: S. Baauw, M. Huiskes \& M. Schoorlemmer (eds.): OTS Yearbook 2002, 105-127. Utrecht: Utrecht Institute of Linguistics.

Hamann, S. (2002b): Retroflexion and Retraction revised. ZAS Papers in Linguistics 28:13-25.

Hamann, S. (2003): The Phonetics and Phonology of Retroflexes. Utrecht: LOT.

Hamann, S. \& M. Rochoń (2002): Preferences in Sibilant Fricative Systems: Postalveolar Puzzlement in Slavic Languages. Poster presented at Eighth Conference on Laboratory Phonology, Yale University and Haskins Labolatories.

Hamilton, W.S. (1980): Introduction to Russian Phonology and Word Structure. Columbus: Slavica Publishers.

Hill, P. (1993): Das Bulgarische. In Reder (ed): Einführung in die slavischen Sprachen, 20-32. Darmstadt: Wissenschaftliche Buchgesellschaft.

Hughes, G. W. \& M. Halle (1956): Spectral Properties of Fricative Consonants. Journal of the Acoustical Society of America 28(2): 303-310.

Hume, E. (1994): Front Vowels, Coronal Consonants and their Interaction in Nonlinear Phonology. London: Garland.

Hume, E. \& K. Johnson (eds.) (2001): The Role of Speech Perception Phenomena in Phonology. San Diego, CA: Academic Press.

Hura, S. Lindblom, B. \& R. Diehl (1992): On the Role of Perception in Shaping Phonological Assimilation Rules. Language and Speech 35, 59-72.

Ivić; P. (1958): Die serbokroatischen Dialekte. Ihre Struktur und Entwicklung. Vol.1 Allgemeines und die štokavischen Dialektgruppe. 'S-Gravenhage: Mouton.

Jassem, W. (1973): Podstawy fonetyki akustycznej. Warszawa: Państwowe Wydawnictwo Naukowe.

Jassem, W., Szybista, D., Krzyśko M., Stolarski P. \& A. Dyczkowski (1976): Rozpoznawanie polskich spółgłosek trących na podstawie cech widmowych. IPPT PAN, 1-41.

Jones, D. \& D. Ward (1969): The Phonetics of Russian. Cambridge: Cambridge University Press.

Keating, P. (1991): Coronal Places of Articulation. In C. Paradis \& J.-F. Prunet (eds.): Phonetics and Phonology. The Special Status of Coronals. Internal and External Evidence, 29-48. New York: Academic Press.

Keating, P. (1993): Phonetic Representation of Palatalization versus Fronting. UCLA Working Papers in Phonetics 85, 6-21.

Kohler, K. (1990): Segmental Reduction in Connected Speech in German: Phonological Facts and Phonetic Explanation. In W.J. Hardcastle \& A. Marchal (eds): Speech Production and Speech Modeling, 69-92. Dordrecht: Kluwer.

Kordić, S. (1997): Serbo-Croatian. München, Newcastle: Lincom Europa.

Kudela, K. (1968): Spectral Analysis of Polish Fricative Consonants. In Jassem, W. (ed.): Speech Analysis and Synthesis. Warszawa: PAN.

Kuðera, H. (1961): The Phonology of Czech. The Hague: Mouton \& co.

Kuraszkiewicz, W. (1972): Gramatyka historyczna języka polskiego. Warszawa: Państwowe Zakłady Wydawnictw Szkolnych.

Johnson, K. (1991): Differential Effects of Speaker and Vowel Variability on Fricative Perception. Language and Speech 34 (3), 265-279.

Ladefoged, P. \& I. Maddieson (1996): The Sounds of the World's Languages. Oxford: Blackwell.

Lahiri, A. \& V. Evers (1991): Palatalization and Coronality. In C. Paradis \& J.-F. Prunet (eds.) Phonetics and Phonology. The Special Status of Coronals. Internal and External Evidence, 79-100. New York: Academic Press.

Lehr-Spławiński, T. (1957): Rozwój historyczny konsonantyzmu czeskiego. In Lehr-Spławiński, T. \& Z. Stieber (eds.): Gramatyka historyczna jezyka czeskiego. Warszawa: Państwowe Wydawnictwo Naukowe.

Lehr-Spławiński, T. \& Z. Stieber (1957): Gramatyka historyczna jezyka czeskiego. Warszawa: Państwowe Wydawnictwo Naukowe.

Leskien, A. (1976): Grammatik der serbo-kroatischen Sprache. Heidelberg. Carl Winter Universitätsverlag.

Lindblad, P (1980): Svenskans sje- och tje-ljud i ett Allmänfonetisk Perspektiv. Travaux de l'Institut de Linguistique de Lund 16.

Lindblom, B., Guion, S. Hura, S. Moon, S-J., \& R. Willerman. (1995): Is Sound Change Adaptive? Rivista di Linguistica 7, 5-37.

Łobacz, P. (1996): Polska fonologia dziecięca. Warszawa: Energeia. 
Maddieson, I. (1984): Patterns of Sounds. Cambridge: Cambridge University Press.

Maddieson, I. \& K. Precota (1990): Updataing UPSID. UCLA Working Papers in Phonetics 74, 104- 111.

Maddieson, I. \& K. Precota (1992): UPSID and Phoneme. UCLA Phonological Segment Inventory DatabaseVersion 1.1.

Mann, V.A. \& B.H. Repp (1980): Influence of Vocalic Context on Perception of the [J]-[s] Distinction. Perception and Psychophysics 23, 213-228.

Mann, V.A. \& S. Soli (1991): Perceptual Order and the Effect of Vocalic Context on Fricative Perception. Perception and Psychophysics 49, 399-411.

Mayo, P. (1993): Belorussian. In B. Combrie \& G. G. Corbett (eds.): The Slavonic Languages, 887- 945. London: Routledge.

Nittrouer, S., Studdert-Kennedy, M \& R.S. McGowan (1989): The Emergence of Phonetic Segments: Evidence From the Spectral Structure of Fricative-Vowel Syllables Spoken by Children and Adults. Journal of Speech and Hearing Research 32, 120-132.

Miletix, R. (1960): Osnovi Fonetike Srpskog Jezika. Belgrade: Nauðna Kniga.

Oliverius, Z. F. (1974): Fonetika Russkovo Jazyka. Prague: Státní Pedagogické Nakladatelství.

Padgett, J. \& M. Zygis (2003): The Evolution of Sibilants in Polish and Russian. ZAS Papers in Linguistics (this volume).

Palkovà, Z. (1994): Fonetika a fonologie češtiny. Praha: Univerzita Karlova.

Pauliny, E., Ružička J. \& J. Štolc (1968): Slovenská Gramatika. Bratislava: Slovenské Pedagogické Nakladatel'stvo.

Priestly, T. M. S. (1993): Slovene. In B. Combrie \& G.G. Corbett, (eds.): The Slavonic Languages, 388- 451. London: Routledge.

Puppel, S., Nawrocka-Fisiak J. \& H. Krassowska (1977): A Handbook of Polish Pronunciation for English Lerners. Warszawa: Państwowe Wydawnictwo Naukowe.

Recasens, D. (1984): Timing Constraints and Coarticulation: Alveolo-Palatals and Sequences of Alveolar $+/ \mathrm{j} / \mathrm{in}$ Catalan. Phonetica 41,125-139.

Recasens, D. (1990): The articulatory characteristics of palatal consonants. Journal of Phonetics 18, 267-280.

Rehder, P. (ed) (1991): Einfuihrung in die slavischen Sprachen. Darmstadt: Wissenschaftliche Buchgesellschaft.

Rehder, P. (1991). Das Serbokroatische. In Reder (ed): Einfuihrung in die slavischen Sprachen, 46-60. Darmstadt: Wissenschaftliche Buchgesellschaft.

Rochon, M.(2000): Optimality in Complexity: the Case of Polish Consonant Clusters. Berlin: Akademie Verlag.

Rochon, M. \& B. Pompino-Marschall (1999): The Articulation of Secondarily Palatalized Coronals in Polish. Proceedings of XIVth International Congress of Phonetic Sciences, San Francisco. 1897-1900.

Rubach, J. (1984): Cyclic and Lexical Phonology. The Structure of Polish. Dordrecht:Foris.Rubach, J. (1993): The Lexical Phonology of Slovak. Oxford: Clarendon Press.

Sawicka, I. (2001): Palatalization as the Main Factor of the Phonetic Development and Typological Diversification of Slavic languages. Ms. Nicolas Copernicus University, Torun, Poland.

Scatton, E. A. (1993): Bulgarian. In B. Combrie \& G.G. Corbett (eds.): The Slavonic Languages, 188- 248. London: Routledge.

Schuster-Šewc, H. (1996): Grammar of the Upper Sorbian Language. München: Lincom Europa.

Šewc, H. (1968): Gramatika hornjoserbskeje rěče. Budyšin: Ludowe nakładnistwo Domowina.

Shevelov, G. V. (1993): Ukrainian. In B. Combrie \& G.G. Corbett (eds.): The Slavonic Languages, 945-998. London: Routledge.

Shadle, C.H. (1985): The Acoustics of Fricative Consonants. Ph.D. thesis, MIT.

Skalicková, A. (1974): Srovnóvací fonetika angličtiny a češtiny. Praha: Československá akademie vẽd.

Stadnik, E. (1998): Phonemtypologie der slawischen Sprachen und ihre Bedeutung für die Erforschung der diachronen Phonologie. Zeitschriff für Slavistik 43(4), 377-400.

Stankiewicz, E. (1986): Polish Mazurzenie and the Serbo-Croatian Palatals. In Stankiewicz (ed.): The Slavic Languages. Unity in Diversity, 105-112. Berlin: Mouton de Gruyter.

Stevens, K. N. (1998): Acoustic Phonetics. Cambridge, Mass.: MIT Press.

Stevens, K.N. (1989): On the quantal nature of speech. Journal of Phonetics 17, 3-45.

Stieber, Z. (1958): Rozwój fonologiczny jezzka polskiego. Warszawa: Państwowe Wydawnictwo Naukowe. 
Stieber, Z. (1966): Historyczna i wspótczesna fonologia języka polskiego. Warszawa: Państwowe Wydawnictwo Naukowe.

Stieber, Z. (1969): Zarys gramatyki porównawczej języków stowiańskich. Fonologia. Warszawa: Państwowe Wydawnictwo Naukowe.

Stieber, Z. (1973): A Historical Phonology of the Polish Language. Heidelberg: Carl Winter Universitätsverlag.

Stojkov, S. (1955): Uvod v balgarskata fonetika. Sofia: Balgarska Akademia na Naukite.

Stone, G. (1993): Sorbian (Upper and Lower). In B. Combrie \& Corbett, G.G. (eds.): The Slavonic Languages, 593- 685. London: Routledge (1993).

Szpyra, J. (1995): Three Tiers in Polish and English Phonology. Lublin: Wydawnictwo Uniwersytetu Marii Curie-Skłodowskiej.

Topolińska. Z. (1974): A Historical Phonology of the Kashubian Dialects of Polish. The Hague: Mouton.

Trávnítek, F. (1951): Mluvnice spisovné čestiny. Praha: Slovanské Nakladatelství.

Wierzchowska, B: (1980) Fonetyka i fonologia jezyka polskiego. Wrocław, Warszawa: Zakład Narodowy im. Ossolińskich: Wydawnictwo Polskiej Akademii Nauk.

Whalen, D.H. (1981): Effects on vocalic formant transitions and vowel quality on the English [s]-[š] boundary. Journal of the Acoustical Society of America 69, 275-282.

Zilyns'kyj, I. (1979): A Phonetic Transcription of the Ukrainian Language. Cambridge, Mass.: Harvard University Press.

Zygis, M. (2003): The Role of Perception in Slavic Sibilant Systems. In P. Kosta, J. Blaszczak, J. Frasek, L. Geist \& M. Zygis (eds.): Investigations into Formal Slavic Linguistics, 137-154. Berlin: Peter Lang Verlag.

Zygis, M. \& S. Hamann (2003): Perceptual and Acoustic Cues of Polish Coronal Fricatives. Proceedings of the $15^{\text {th }}$ International Congress of Phonetic Sciences, Barcelona 3-9 August. 395-398. 
